\title{
Numerical Modeling of an Automotive Derivative Polymer Electrolyte Membrane Fuel Cell Cogeneration System with Selective Membranes
}

\author{
Gabriele Loreti ${ }^{\mathrm{a}}$, Andrea Luigi Facci ${ }^{\mathrm{a}, *}$, Thijs Peters $^{\mathrm{b}}$, Stefano Ubertini $^{\mathrm{a}}$ \\ ${ }^{a}$ DEIM Department of Economics, Engineering, Society and Business Administration, University of Tuscia, 01100 Viterbo, Italy \\ ${ }^{b}$ SINTEF Industry, P.O. Box 124 Blindern, N-0314, Oslo, Norway
}

\begin{abstract}
Cogeneration power plants based on fuel cells are a promising technology to produce electric and thermal energy with reduced costs and environmental impact. The most mature fuel cell technology for this kind of applications are polymer electrolyte membrane fuel cells, which require high-purity hydrogen.

The most common and least expensive way to produce hydrogen within today's energy infrastructure is through steam reforming of natural gas. Such a process produces a syngas rich in hydrogen that has to be purified to be properly used in low temperature fuel cells. However, the hydrogen production and purification processes strongly affect the performance, the cost, and the complexity of the whole energy system.

Purification is usually performed through pressure swing adsorption, which is a semi-batch process that increases the plant complexity and incorporates a substantial efficiency penalty. A promising alternative option for hydrogen purification is the use of selective metal membranes that can be integrated in the reactors of the fuel processing plant. Such a membrane separation may improve the thermo-chemical performance of the energy system, while reducing the power plant complexity, and potentially its cost. Herein, we perform a technical analysis, through thermo-chemical models, to evaluate the integration of Pd-based $\mathrm{H}_{2}$-selective membranes in different sections of the fuel processing plant: (i) steam reforming reactor, (ii) water gas shift reactor, (iii) at the outlet of the fuel processor as a separator device. The results show that a drastic fuel processing plant simplification is achievable by integrating the Pd-membranes in the water gas shift and reforming reactors. Moreover, the natural gas reforming membrane reactor yields significant efficiency improvements.
\end{abstract}

Keywords: CHP, Fuel Cell, Hydrogen, Membrane reactor

\section{Introduction}

Residential and commercial buildings are responsible for $38.0 \%$ of the final energy consumed worldwide [1]. Moreover, about $30.0 \%$ of $\mathrm{CO}_{2}$ emissions related to energy conversion [2] are caused by the building sector. The increase of households, the population rise, and the fragmentation of households will generate in the next years an increment in heating and cooling energy needs, and of electricity consumption, despite efficiency improvements in the final use [1-3]. In this scenario, Combined Heating and Power (CHP) could bring

\footnotetext{
${ }^{*}$ Corresponding author

Email addresses: gabriele.loreti@unitus.it (Gabriele Loreti), andrea.facci@unitus.it (Andrea Luigi Facci), Thijs.Peters@sintef .no (Thijs Peters), stefano.ubertini@unitus.it (Stefano Ubertini)
}

relevant economical, environmental, and energetic advantages [4], such as: (i) higher total efficiency, thanks to thermal recovery [5, 6], (ii) less greenhouse gases and pollutants emissions [5, 7], (iii) deferring investment on large centralized power plants and distribution lines [5, 7], (iv) lower distribution losses [7], (v) ancillary service to the main electric energy distribution grid [7], (vi) optimal integration of new and alternative technologies, such as renewable enery sources [5, 8-11]. In particular [12] $\mu$-CHP $\left(10^{-3} \mathrm{~kW}<P_{\mathrm{el}}<5 \mathrm{~kW}\right)$ and small-CHP $\left(5 \mathrm{~kW}<P_{\mathrm{el}}<5 \times 10^{3} \mathrm{~kW}\right)$ systems are suitable for residential and commercial building applications and have a great innovation potential, given the large market size. In particular, only in the US, more than 1 Million new residential units are built every year [13] and the trend is positive again.

Fuel Cells (FCs) are an emerging technology in the stationary field, particularly for distributed CHP power

June 16, 2018 


\section{Nomenclature}

A

$A_{\mathrm{memb}}^{\mathrm{SEP}}$

Selective membranes surface

$A_{\mathrm{memb}}^{\mathrm{WGS}}$

$A_{\mathrm{memb}}^{\mathrm{REF}}$

$d A$

Selective membranes surface for Plant B

$\dot{m}_{\mathrm{H}_{2}}$

Hydrogen mass flow rate

Selective membranes surface for Plant $C$

$\dot{m}_{\mathrm{NG}}$

Natural gas mass flow rate

$\dot{m}_{\mathrm{NG}}^{\mathrm{BURN}}$

Natural gas mass flow rate to the burner

Selective membranes surface for Plant D

$\dot{m}_{\mathrm{NG}}^{\mathrm{REF}}$

Natural gas mass flow rate to the reformer

$\dot{m} \quad$ Heat exchangers mass flow rate

CHP Combined Heating and Power

$n$

Pressure exponent

$\Delta \mathrm{T}_{\mathrm{ml}} \quad$ Logarithmic mean temperature difference

$\eta_{\mathrm{FC}} \quad$ Fuel Cell efficiency

$\eta_{\mathrm{fp}} \quad$ Fuel processor efficiency

$\eta_{\mathrm{fp}}^{\text {tot }} \quad$ Fuel processor total efficiency

$\eta_{\text {glob }} \quad$ Global efficiency

$\eta^{\text {is }} \quad$ Isoentropic efficiency of pumps or compressors

$\eta^{\mathrm{SEP}} \quad$ Hydrogen separation efficiency

$\eta_{\text {th }} \quad$ Thermal efficiency

FCH-JU Fuel Cells and Hydrogen Joint Undertaking

FCs $\quad$ Fuel Cells

$\dot{f}^{\text {syn }} \quad$ Initial syngas mole flow

$\dot{f}_{\mathrm{H}_{2}}^{\text {syn }} \quad$ Initial hydrogen mole flow

$\Gamma \quad$ Product of surface and thermal conductivity for heat exchangers

$h \quad$ Fluids enthalpy

HIWAR Heat Integrated Wall Reactor

$j_{\mathrm{H}_{2}} \quad$ Infinitesimal hydrogen permeation flux

$J_{\mathrm{H}_{2}} \quad$ Hydrogen permeation flux

$K_{\mathrm{H}_{2}} \quad$ Hydrogen permeance of the selective membrane

$\mathrm{NG}$

$n_{\mathrm{H}_{2} \text {,syn }} \quad$ Initial number of $\mathrm{H}_{2}$ moles in the syngas

$n_{\text {tot }} \quad$ Total number of moles in the retentate

PEMFCs Polymer Electrolyte Membrane Fuel Cells

$p^{\mathrm{REF}} \quad$ Reforming reactor pressure

PSA Pressure Swing Adsorption

$P_{\mathrm{el}} \quad$ FC net electrical power

$P_{\mathrm{el}}^{\text {nom }} \quad$ FC nominal net electrical power

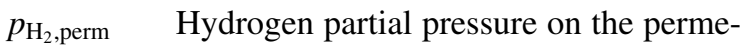
ate side

$p_{\mathrm{H}_{2} \text {,ret }} \quad$ Hydrogen partial pressure on the retentate side

$p_{\text {perm }} \quad$ Total pressure on the permeate side

$p_{\text {ret }} \quad$ Total pressure on the retentate side

$\psi \quad$ Ratio between the mass flow rates of the natural gas and of the steam entering the reformer

$Q \quad$ Heat exchangers thermal power

$Q_{\operatorname{cog}} \quad$ Cogeneration thermal power

$\Phi \quad$ set-point

$T_{\mathrm{COG}} \quad$ Temperature of cogeneration water

$T^{\mathrm{REF}} \quad$ Reforming reactor temperature

$K_{\mathrm{REF}} \quad$ Reforming chemical reaction equilib-

WGS Water Gas Shift

$W_{\mathrm{aux}}^{\text {ref }} \quad$ Power required by the auxiliaries of the fuel processor

$K_{\text {WGS }} \quad$ WGS chemical reaction equilibrium constant

$\mathrm{LHV}_{\mathrm{H}_{2}} \quad$ Hydrogen lower heating value

LHV $_{\text {NG }} \quad$ Natural gas lower heating value

$y_{\mathrm{H}_{2}}$

$y_{\mathrm{H}_{2}}^{\min }$
Hydrogen concentration in the retentate

Minimum hydrogen concentration in the retentate 
plants in residential and commercial applications [1419]. The most promising aspects of FCs for this application are: (i) the high efficiency [20], which is independent from the size and increases at part load [21-24], (ii) the low level of pollutant emission [25], (iii) the absence of moving parts that results in no noise and no vibrations [26]. It is not a case, in fact, that $64.0 \%$ of the micro co-generation [12] units sold in 2012 are based on fuel cells [16, 27, 28].

Among the different kinds of fuel cells, Polymer Electrolyte Membrane Fuel Cells (PEMFCs) are technologically mature and provide several advantages [2224]: (i) low operating temperature, (ii) fast start-up and regulation capability, (iii) high power density. Such characteristics make PEMFCs the most mature technology in the market. In fact, $75 \%$ of new-installed FC units in 2017 were PEMFCs [29].

The high investment cost of FC-based CHP units is still the most relevant drawback with respect to conventional technologies. Commercial FC based small-CHP systems costs are far higher than the Fuel Cells and Hydrogen Joint Undertaking (FCH-JU) goals [30]. For energy systems with a nominal power in the range $\left[5 \mathrm{~kW}_{\mathrm{el}}\right.$ - $400 \mathrm{~kW}_{\mathrm{el}}$ ] [31], the FCH-JU has set a cost target between $3500 € / \mathrm{kW}_{\mathrm{el}}$ and $6500 € / \mathrm{kW}_{\mathrm{el}}$. For FCs the mobility market volume is much larger than the stationary sector. In fact, $68 \%$ of the power of the FC energy systems developed in 2017 is attributable to transport applications [29]. As a consequence, the usage of automotive derivative PEMFCs for stationary systems can be an interesting option [32], being the cost of energy systems a decreasing function when the production volume increases [33-36]. The objective of the AutoRE project [32] is to build a constructive collaboration between the mobility and the stationary industrial sectors, in order to establish the basis for the commercialization of an automotive derivative PEMFC based CHP system with a capital cost of $2000 € / \mathrm{kW}_{\mathrm{el}}$ and in the power range between $50 \mathrm{~kW}_{\mathrm{el}}$ and $100 \mathrm{~kW}_{\mathrm{el}}$ [32].

Nowadays, high-purity $\mathrm{H}_{2}$ can be produced from hydrocarbons through the following steps [37]: (i) steam reforming, (ii) conversion of CO through the Water Gas Shift (WGS) reaction, (iii) final purification through Pressure Swing Adsorption (PSA) . In such a fuel processing unit, the separation of $\mathrm{H}_{2}$ can represent up to $50 \%$ of the plant cost and significantly reduces the overall efficiency [38].

Dense metal membrane technology can be integrated into the $\mathrm{H}_{2}$ production process in various ways, either with a WGS stage replacing the PSA process, or by direct integration in the reformer. The main benefit of the integration of a palladium membrane directly in a steam reformer would be that the produced hydrogen is directly removed from the reaction zone at ultra-high purity, while additional purification steps are not required. Selective membranes can be made of several materials such as silica gel, zeolite, high temperature organic thermoplastic polymers and other metals such as aluminum [39.-42], however here we focus on dense metal membranes made of Pd-Ag alloys, being the kind of technology most mature and the most suitable for our purposes.

Several studies have been performed in order to evaluate the integration of selective membranes in different parts of Natural Gas (NG) steam reforming based hydrogen production systems [43-47]. In this work we focus on the fuel processor of a $50 \mathrm{~kW}_{\mathrm{el}} \mathrm{CHP}$ power plant based on low temperature automotive derivative PEMFCs. Such an application and such a power range are almost untapped. Moreover, we retrieve part load performance, in order to lay the foundation of a study considering the CHP system in a real energy management scenario.

Many studies focus on the single component development for membrane reactors using several experimental or modeling techniques [39,-42, 48,-55], however here we are interested in retrieving the performance of the whole energy system.

We assume that the hydrogen has to be locally produced by NG coming from the distribution grid. However, we underline that the energy system in study could in principle operate on both $\mathrm{H}_{2}$ (from water electrolysis) or natural gas, or a combination of the two [32]. Nowadays, it is necessary to develop efficient fuel processing plants in order to penetrate the market of distributed generation with FC technologies in the short medium term. Consequently, the CHP system can use existing infrastructure of NG, while being ready, and more competitive, for $\mathrm{H}_{2}$ re-electrification, when renewable energy surplus makes $\mathrm{H}_{2}$ generation a viable energy storage option [8, 56, 57].

Moreover, we underline that the technology of selective membranes can be used to process by steam reforming several fuels such as methanol, ethanol and glycerol [42, 49, 50, 53, 55], and also in other processes such as one step DME production process fed by $\mathrm{CO}_{2}$ rich streams [40].

The paper is organized as follows. In section 2 the CHP system in study is presented. The numerical modeling methodology is accurately described in section 3 . In section 4 the different fuel processing layouts analyzed are presented and characterized. Some in depth comparisons between the several case studies are presented in section 5. Finally, in section 6 we draw the conclusions of the work. 


\section{Problem Statement}

The aim of this paper is to assess the impact of $\mathrm{H}_{2}$ selective membranes [37, 44] on the performance, cost, and system complexity reduction of the $50 \mathrm{~kW}_{\mathrm{el}}$ PEMFC based CHP plant, represented in Figure1. Such a plant is connected to the NG line through a fuel processor based on SR, WGS, and syngas purification, that significantly impacts its performance.

\subsection{Fuel Cell Based CHP Plant}

We consider the $50 \mathrm{~kW}_{\mathrm{el}} \mathrm{CHP}$ power plant represented in Figure 1] The prime mover is an automotive derivative low temperature PEMFC that converts hydrogen into electrical energy [32].

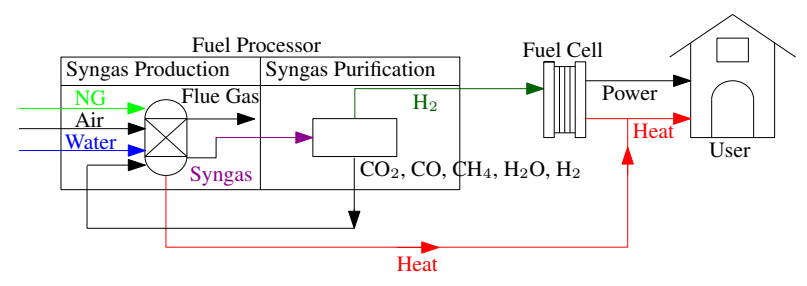

Figure 1: Schematic of the cogenerative PEM fuel cell system.

The low temperature PEMFC requires very high purity $\mathrm{H}_{2}$ (i.e. $99.999 \%$, according to SAE J2719 [58]) that, in the near future, must be locally produced through a fuel processor (see Figure 1p because a diffused distribution grid for hydrogen is not present yet. A hydrogen rich syngas is obtained through NG steam reforming and WGS [37, 59]. Different technologies, including pressure swing adsorption separators and selective membranes [37], can be utilized to purify the syngas.

Fuel processing and purification strongly affect the overall performance of the considered energy system [38]. In fact, with a prime mover electrical efficiency in the range $[45 \%, 55 \%]$ [22- 24, 38], the resulting overall plant efficiency is between $32 \%$ and $38 \%$ [38] when utilizing a PSA. Such an efficiency is below the $42 \%$ target set by the FCH-JU [31].

We focus on the fuel processor technology. Specifically, we analyze the option of utilizing Pd-based selective membranes to separate pure $\mathrm{H}_{2}$ from reformate gas. We compare three configurations obtained by placing the membranes as separator device or integrating them in the WGS or SR reactors. The global efficiency is the principal performance parameter and is evaluated through the following equation:

$$
\eta_{\mathrm{glob}}=\frac{P_{\mathrm{el}}-W_{\mathrm{aux}}^{\mathrm{ref}}}{\dot{m}_{\mathrm{NG}} \mathrm{LHV} V_{\mathrm{NG}}}
$$

where $P_{\text {el }}$ is the FC net electrical power, $W_{\text {aux }}^{\text {ref }}$ is the power required by the auxiliaries of the fuel processing section, $\dot{m}_{\mathrm{NG}}$ is the total natural gas mass flow entering in the energy system and $\mathrm{LHV}_{\mathrm{NG}}=46.5 \mathrm{MJ} / \mathrm{kg}$ is the lower heating value of the natural gas. Note that in the evaluation of the global efficiency (eq. (1)) the electric power output $P_{\mathrm{el}}$ is a net value, as evidenced in a previous work [38], already reduced of the power required by the auxiliaries of the FC plant (feeding air compressor and refrigerant circulation pumps). The fuel processor efficiency (eq. (2)) is also defined as:

$$
\eta_{\mathrm{fp}}=\frac{\dot{m}_{\mathrm{H}_{2}} \mathrm{LHV}_{\mathrm{H}_{2}}}{\dot{m}_{\mathrm{NG}} \mathrm{LHV}_{\mathrm{NG}}} .
$$

where $\dot{m}_{\mathrm{H}_{2}}$ is the mass flow of $\mathrm{H}_{2}$ and $\mathrm{LHV}_{\mathrm{H}_{2}}=$ $120 \mathrm{MJ} / \mathrm{kg}$ is its lower heating value. Moreover, the effect of auxiliaries can be considered also for the fuel processor efficiency leading to the expression reported in eq. (3).

$$
\eta_{\mathrm{fp}}^{\text {tot }}=\frac{\dot{m}_{\mathrm{H}_{2}} \mathrm{LHV}_{\mathrm{H}_{2}}-W_{\mathrm{aux}}^{\mathrm{ref}}}{\dot{m}_{\mathrm{NG}} \mathrm{LHV}} .
$$

Finally, we evaluate the thermal efficiency as follows:

$$
\eta_{\text {th }}=\frac{Q_{\mathrm{cog}}}{\dot{m}_{\mathrm{NG}} \mathrm{LHV} V_{\mathrm{NG}}},
$$

where $Q_{\operatorname{cog}}$ is the thermal power available via cogeneration from the CHP plant.

The efficiencies are functions of the plant set-point, defined as:

$$
\Phi=\frac{P_{\mathrm{el}}}{P_{\mathrm{el}}^{\text {nom }}},
$$

where $P_{\mathrm{el}}^{\mathrm{nom}}=50 \mathrm{~kW}_{\mathrm{el}}$ is the maximum net electric power, and $P_{\mathrm{el}}$ is the net power output obtained by regulating the power plant.

\subsection{Selective Membranes}

Selective membranes, such as Pd-Ag alloys are a viable alternative to PSA [44].Such membranes can reach efficiencies comparable or larger than PSA [44] and can operate at relatively high temperature $\left(300^{\circ} \mathrm{C}-700^{\circ} \mathrm{C}\right)$ [60]. Thus, selective membranes at the state of the art can be integrated directly within the water gas shift and reforming reactor shifting chemical equilibrium towards larger hydrogen values. Membrane reactors have thus a potential in terms of plant simplification, in particular eliminating the necessity of syngas dehydration and the semi-batch PSA process. As a drawback, hydrogen is obtained at lower pressure (to ensure the driving force for separation), and thus hydrogen compression might be required after separation. 
For application of selective membranes at low temperature (i.e. as a simple separators) the stability can be guaranteed overcoming the phase change by alloying Pd with other metals such as $\mathrm{Cu}, \mathrm{Ag}$, and $\mathrm{Au}$ [60].

Different configurations, with respect to the integration of selective membranes within a reformer reactor are presented in literature [44], such as integrating the membranes directly in the steam reformer or in an autothermal reactor, or in the WGS reactor. The integration of the membranes in the steam reformer as well as the utilization of an autothermal reactor would require a substantial modification of the whole reforming plant.

\section{Methodology}

We perform the steady state modeling of the power plants introduced in section 2 using a lumped parameter approach. The simulation software is Aspen Plus ${ }^{\circledR}$ [61], integrated with proprietary Fortran codes. The modeling strategy is consistent with other studies found in literature [38, 44, 62, 63].

The main components of the analyzed power plants are: (i) Membrane Separator; (ii) Heat Integrated Wall Reactor (HIWAR) ; (iii) Membrane Integrated Reforming Reactor; (iv) Water Gas Shift Reactor; (v) Membrane Integrated Water Gas Shift Reactor; (vi) Heat Exchangers; (vii) Auxiliaries; (viii) Automotive Derivative Fuel Cell; (ix) PSA Separator.

In the modeling environment we use the Peng Robinson equation [61] of state to compute the thermodynamic properties of working fluids. In addition, for pure water streams, the steamNBS tables are used [64].

\subsection{Membrane Separator}

The conceptual scheme for a membrane separator is shown in Figure 2 $\mathrm{H}_{2}$ permeation through a $\mathrm{Pd}$ mem-

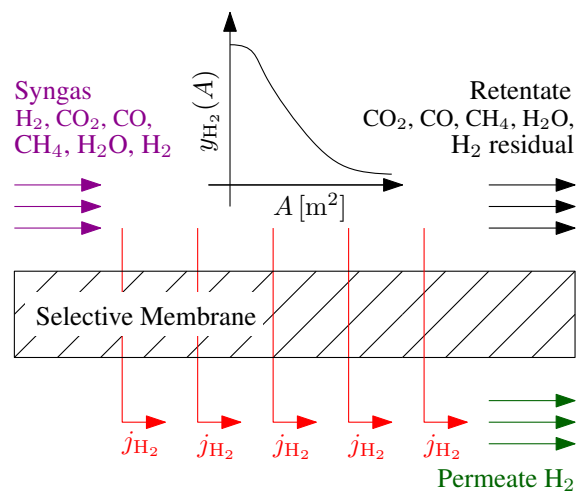

Figure 2: Membrane separator scheme and nomenclature. brane is described by the well-known Sieverts' law [65], which is expressed by eq. (6), in the case that $\mathrm{H}_{2}$ diffusion through the bulk of Pd membrane is rate-limiting, i.e. the $\mathrm{H}_{2}$ flux is proportional to the square root of the $\mathrm{H}_{2}$ partial pressure difference $(n=0.5)$.

$$
j_{\mathrm{H}_{2}}=K_{\mathrm{H}_{2}}\left(p_{\mathrm{H}_{2}, \text { ret }}^{n}-p_{\mathrm{H}_{2} \text {,perm }}^{n}\right),
$$

where $K_{\mathrm{H}_{2}}$ is the hydrogen permeance of the membrane, $p_{\mathrm{H}_{2} \text {,ret }}$ and $p_{\mathrm{H}_{2} \text {,perm }}$ are the $\mathrm{H}_{2}$ partial pressure on the retentate and permeate sides of the membrane, respectively. Deviations from Sieverts' law behavior (i.e. $n>0.5$ ) have been attributed to various factors including surface and gas diffusion limitations, and have been used in literature to investigate the rate-controlling step of the permeation of $\mathrm{H}_{2}$ through a Pd-based membrane. The main factors determining the hydrogen permeance are the thickness of the membrane selective layer and the temperature [66]. State of the art membranes reach permeance values around $10^{-2} \mathrm{~mol} /\left(\mathrm{m}^{2} \mathrm{sPa}^{0.5}\right)$ at $350-$ $400{ }^{\circ} \mathrm{C}$, thereby reaching values higher than the 2015 target set by the U.S. DoE $\left(8.5 \times 10^{-3} \mathrm{~mol} /\left(\mathrm{m}^{2} \mathrm{sPa}^{0.5}\right)\right)$ [67]. However, these values are obtained in pure $\mathrm{H}_{2}$ as feed gas where there are no surface and gas diffusion limitations for transport. Measurements obtained under real operating conditions have shown that the permeance can be decreased by roughly a factor of 5 compared to a situation where pure $\mathrm{H}_{2}$ is applied as feed. In the current modelling study, we have therefore investigated the membrane performance assuming a permeance value of $8.5 \times 10^{-3} \mathrm{~mol} /\left(\mathrm{m}^{2} \mathrm{sPa}^{0.5}\right)$, which is the DoE target, and a permeance value one order of magnitude lower $\left(8.5 \times 10^{-4} \mathrm{~mol} /\left(\mathrm{m}^{2} \mathrm{sPa}^{0.5}\right)\right)$.

Referring to eq. (6), the driving force vanishes when $p_{\mathrm{H}_{2} \text {,ret }}=p_{\mathrm{H}_{2} \text {,perm. }}$. Note that we assume the absence of a sweep flow in the permeate side to have a better performing FC [46]. Thereafter, the minimum hydrogen concentration possible in the retentate is $y_{\mathrm{H}_{2}}^{\min }=$ $p_{\text {perm }} / p_{\text {ret }}$ and can be reached only by using an infinite surface membrane.

The following equation evaluates the $\mathrm{H}_{2}$ concentration in the retentate as a function of the membrane area $A\left(y_{\mathrm{H}_{2}}(A)\right)$ :

$$
y_{\mathrm{H}_{2}}(A)=\frac{n_{\mathrm{H}_{2}, \mathrm{syn}}-\int_{0}^{A} j_{\mathrm{H}_{2}}(A) d A}{n_{\mathrm{tot}}(A)},
$$

where $n_{\mathrm{H}_{2} \text {,syn }}$ is the initial number of $\mathrm{H}_{2}$ moles in the syngas and $n_{\text {tot }}(A)$ is the total number of moles in the retentate. Equation (7) is numerically integrated using the Euler method to obtain $y_{\mathrm{H}_{2}}(A)$ shown in Figure 3 . Therein, we consider the following retentate and the 
permeate total pressures, $p_{\text {ret }}=11.5 \mathrm{bar}$ and $p_{\text {perm }}=$ 1.20 bar, respectively. The initial syngas mole flow is $\dot{f}^{\text {syn }}=0.944 \mathrm{~mol} / \mathrm{s}$, carrying a hydrogen mole flow $\dot{f}_{\mathrm{H}_{2}}^{\mathrm{syn}}=0.482 \mathrm{~mol} / \mathrm{s}$. The selectivity of the membrane is assumed to be infinite, and hydrogen is separated. For the integration of eq.(7), we assume $d A=10^{-3} \mathrm{~m}^{2}$ after a convergence analysis on the total pure hydrogen flux $J_{\mathrm{H}_{2}}$. Figure 3 evidences that $K_{\mathrm{H}_{2}}$ influences the area required for the separation, but not $y_{\mathrm{H}_{2}}^{\min }$, or in other words the separation efficiency.
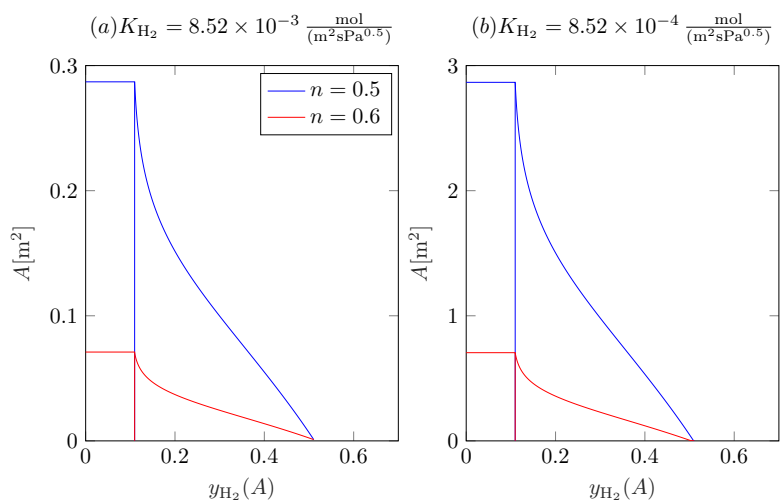

Figure 3: Variation of the surface of the membrane separator with respect to the hydrogen concentration in the retentate, as a function of the driving force exponent in two different cases: a) $K_{\mathrm{H}_{2}}=8.52 \times$ $10^{-3} \mathrm{~mol} /\left(\mathrm{m}^{2} \mathrm{sPa}^{0.5}\right)$; b) $K_{\mathrm{H}_{2}}=8.52 \times 10^{-4} \mathrm{~mol} /\left(\mathrm{m}^{2} \mathrm{sPa}^{0.5}\right)$.

For $y_{\mathrm{H}_{2}} \geq 0.2$ (i.e. $y_{\mathrm{H}_{2}} \geq 1.92 y_{\mathrm{H}_{2}}^{\min }$ ) the membrane area increases linearly by reducing the $\mathrm{H}_{2}$ concentration (see Figure 3. Conversely, a further reduction of $y_{\mathrm{H}_{2}}$ causes a sharp increment of the required surface. Thus, in the followings, we assume that the $\mathrm{H}_{2}$ concentration at the exit of the membrane separator is $y_{\mathrm{H}_{2}}=1.05 y_{\mathrm{H}_{2}}^{\mathrm{min}}$ and we denote $J_{\mathrm{H}_{2}}=\int_{0}^{A} j_{\mathrm{H}_{2}}(A) d A$. The separation efficiency (also known as hydrogen recovery factor) is defined as:

$$
\eta^{\mathrm{SEP}}=\frac{J_{\mathrm{H}_{2}}}{\dot{f}_{\mathrm{H}_{2}}^{\mathrm{syn}}} .
$$

The retentate pressure largely determines $\eta^{\mathrm{SEP}}$ through its influence on $y_{\mathrm{H}_{2}}^{\min }$, as evidenced in Figure 4 Specifically, $\eta^{\mathrm{SEP}}$ increases from $2.65 \%$ to $89.3 \%$ varying $p_{\text {ret }}$ from 2.50 bar to 12.5 bar. On the contrary it further increments just to $94.3 \%$ increasing $p_{\text {ret }}$ to 22.5 bar.

\subsection{HIWAR}

Steam reforming is performed in the HIWAR [68 69], where the catalytic oxidation of natural gas and

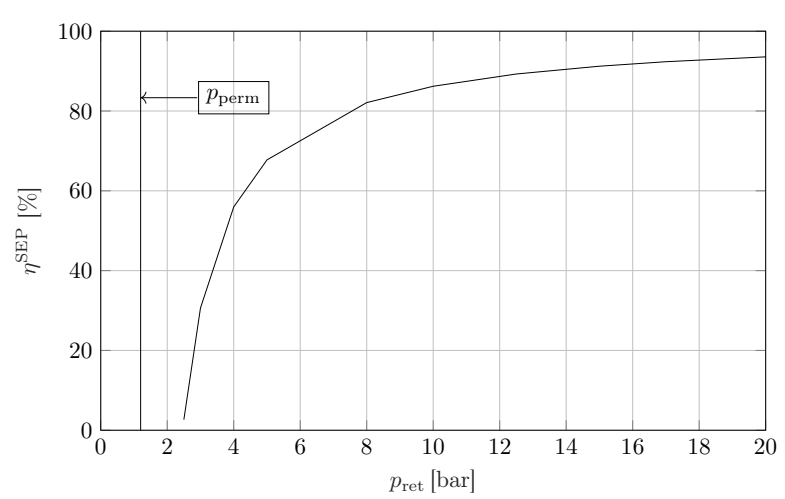

Figure 4: Maximum attainable separation efficiency of Pd-based selective membranes as a function of the feed pressure, for $p_{\text {perm }}=$ $1.20 \mathrm{bar}, \dot{f}^{\text {ret }}=0.944 \mathrm{~mol} / \mathrm{s}, \dot{f}_{\mathrm{H}_{2}}^{\text {ret }}=0.482 \mathrm{~mol} / \mathrm{s}$, and $y_{\mathrm{H}_{2}}=1.05 y_{\mathrm{H}_{2}}^{\min }$.

the steam reforming reactions take place in a single element. Such a device is a ceramic tube coated with a metal catalyst film, specific for the oxydation, in its inner side and with another catalytic substance, specific for the reforming, in the outer. The heat flux between the two sides of the reactor is allowed by the conductive wall.

In our model such a component is simulated through two separate reactors. The coupling of the elements, i.e. the heat integration, is then implemented through an heat flux from the burner to the reformer (Figure 5).

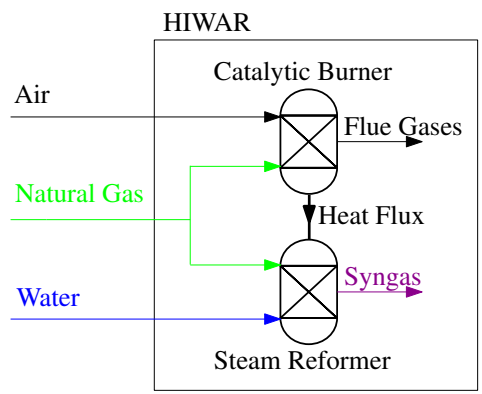

Figure 5: Schematic overview of the HIWAR reactor model.

The temperature of the catalytic burner is $845^{\circ} \mathrm{C}$. Thus a common equilibrium reactor would be not effective. Therefore, we use the stoichiometric reactor (RStoic in Aspen Plus ${ }^{\circledR}$ ) and specify the chemical reactions that take place and the associated fractional conversion. The following equation reports the reactions implemented for the catalytic burner reactor:

$$
\left\{\begin{array}{l}
2 \mathrm{H}_{2}+\mathrm{O}_{2} \rightarrow 2 \mathrm{H}_{2} \mathrm{O} \\
\mathrm{C}_{x} \mathrm{H}_{z}+\left(\frac{z}{4}+x\right) \mathrm{O}_{2} \rightarrow \frac{z}{2} \mathrm{H}_{2} \mathrm{O}+x \mathrm{CO}_{2} .
\end{array}\right.
$$


The fractional conversion of each oxidized element is set to $100 \%$.

The steam reforming is modeled as an equilibrium reactor (called RGibbs in the modeling environment). Aspen Plus ${ }^{\circledR}$ calculates the equilibrium composition of the resulting flows minimizing the Gibbs free energy [61]. The temperature and pressure of the reactor will determine the prevailing reactions through the equilibrium constants. The reforming side of the HIWAR reactor is operated at a temperature of $770^{\circ} \mathrm{C}$. The following equation, reports the dominant reactions at such a temperature:

$$
\left\{\begin{array}{l}
\mathrm{C}_{x} \mathrm{H}_{z}+x \mathrm{H}_{2} \mathrm{O} \rightleftharpoons\left(x+\frac{z}{2}\right) \mathrm{H}_{2}+x \mathrm{CO}, \\
\mathrm{CO}+\mathrm{H}_{2} \mathrm{O} \rightleftharpoons \mathrm{CO}_{2}+\mathrm{H}_{2} .
\end{array}\right.
$$

Note that at $770^{\circ} \mathrm{C}$, the chemical reaction equilibrium constants for methane (the main component of NG) steam reforming and water gas shift are $K_{\mathrm{REF}}=84.4$ and $K_{\mathrm{WGS}}=1.21$ [70] respectively. The NG steam reforming is the largely predominant reaction, being $K_{\mathrm{REF}} \cong 70 \times K_{\mathrm{WGS}}$.

\subsection{Water Gas Shift Reactor}

The water gas shift reaction is conventionally applied in fuel processing plants, to produce further hydrogen from carbon monoxide and water, as follows:

$$
\mathrm{CO}+\mathrm{H}_{2} \mathrm{O} \rightleftharpoons \mathrm{CO}_{2}+\mathrm{H}_{2} \text {. }
$$

We utilize the stoichiometric equilibrium reactor that allows the user to specify the stoichiometry of the reactions that has to be simulated (in this case the reaction reported in eq. (11)). Such a modeling choice is required to exclude the steam reforming reaction from chemical equilibrium computations. The reforming reaction besides having a lower equilibrium constant compared to reaction (11) is also kinetically hindered: at $320^{\circ} \mathrm{C}$, the chemical reaction equilibrium constants for water gas shift and methane steam reforming are $K_{\mathrm{WGS}}=24.9$ and $K_{\mathrm{REF}}=2.32 \times 10^{-7}[70]$ respectively, and this reactor utilizes specific catalysts to promote reaction (11) rather than steam reforming. For these reasons, the water gas shift is largely predominant.

\subsection{Membrane Reforming and Water Gas Shift Reac- tors}

Pd-based selective membranes resist to relatively high temperatures and pressures and thus can be integrated directly in reactors (Figure 6). In this way the hydrogen produced is separated from the reactants, shifting the reaction towards products. The integration can

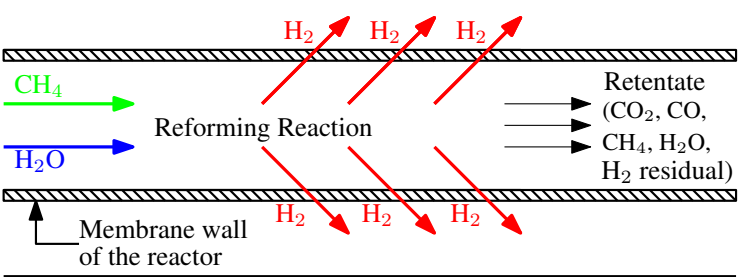

Figure 6: Schematic overview of membrane reactors.

be performed both in the water gas shift and in the reforming reactors.

For these processes we have developed a 1-D reactor model in Aspen Plus ${ }^{\circledR}$, that is an inherently 0-D simulation environment. To this aim, we discretize the membrane reforming and membrane WGS as a sequence of reactors and separators, as shown in Figure 7 .

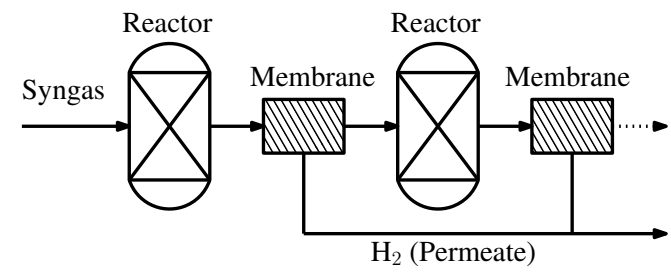

Figure 7: Modeling approach used for the membrane reactors.

To determine the most appropriate number of discretization steps a convergence analysis is performed. Specifically, the mass flow of the pure hydrogen produced by the fuel processing plant is considered as the convergence parameter. We verified that the $\mathrm{H}_{2}$ flow varies less then a $1 \%$ by incrementing the number of discretization steps from five to six, for both reforming and water gas shift reactor. Therefore, 6 steps are used for the discretization of all membrane reactors.

\subsection{Heat Exchangers}

All heat exchangers are studied through the logarithmic mean temperature difference model. An accurate modeling of the off-design performance is considered, since the thermal resistance varies as a function of the hydrogen mass flow rate. In design conditions the product between the heat exchange coefficient and the area of the heat exchanger is calculated as [71]:

$$
\Gamma^{*}=\frac{Q}{\Delta \mathrm{T}_{\mathrm{ml}}},
$$


where $Q$ is the thermal power and $\Delta \mathrm{T}_{\mathrm{ml}}$ the logarithmic mean temperature difference.

When mass flows change, the product $U A$ is calculated as:

$$
\Gamma=\Gamma^{*}\left(\frac{\dot{m}}{\dot{m}^{*}}\right)^{0.8},
$$

where $\dot{m}$ and $\dot{m}^{*}$ are the mass flows in off-design and design conditions respectively.

When $\dot{m} \neq \dot{m}^{*}$ for both the hot and the cold side of the heat exchanger, the mass flow with the lower heat transfer coefficient is considered in eq. (13).

In several heat exchangers, the heat capacity of one or both the flows varies due to condensation or evaporation. In such cases, a single heat exchanger is subdivided into several elements and the number of discretization steps is determined through a convergence analysis. The output enthalpy of hot and cold streams is selected as convergence parameter. The most critical case (i.e. HE-5 in Figure 17p converges for 10 discretization steps. Thus all the heat exchangers are subdivided into 10 elements.

\subsection{Auxiliaries}

Several fluid machineries provide the required pressure to the fluids in each plant section. Specifically, there are: (i) a natural gas compressor, (ii) a water pump for the high pressure steam generation, (iii) an air compressors for circulation, (iv) an air compressor for the fuel cell, (v) two water pumps for circulation in the fuel cell balance of plant and, in some cases, (vi) an hydrogen compressor.

The power required from the auxiliaries, is evaluated as:

$$
W_{\mathrm{aux}}=\eta^{\mathrm{is}}\left(h^{\mathrm{out}}-h^{\mathrm{in}}\right),
$$

where $h$ is the enthalpy of the fluid calculated from the Peng Robinson equation [61] of state and $\eta^{\text {is }}$ is the isoentropic efficiency of the pump/compressor. Values for the efficiency of the devices are retrieved from an Aspen Plus library of real machines.

\subsection{Automotive Derivative Fuel Cell}

The main components of the fuel cell model are (Figure 8): (i) the PEMFC stack, (ii) the air compressor, (iii) two cooling circuit with different temperature levels, (iv) two pumps for water circulation, (v) two heat exchanger for co-generation. In the model a control system is also simulated, in order to maintain the proper ratio between air and hydrogen mass flows.

The cathodic exhaust and the high temperature cooling circuit stream of the fuel cell are exploited for cogeneration purposes.

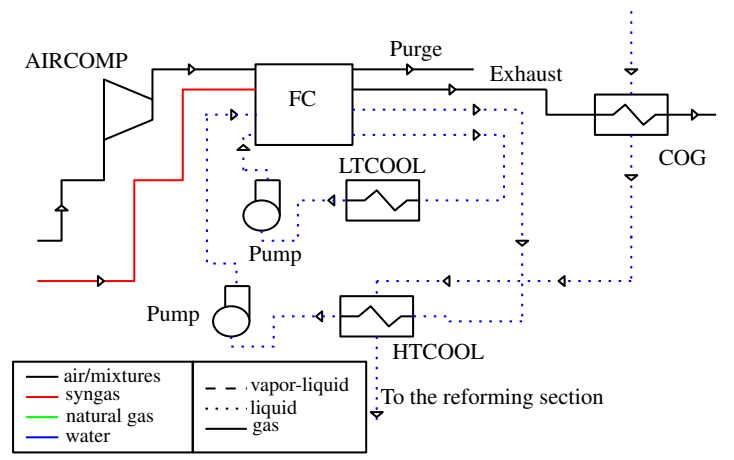

Figure 8: Schematic representation of the model implemented for the fuel cell.

The model of the PEMFC stack relies on experimental data of the automotive FC provided by NuCellSys and reported in Figure 9. Specifically the blackbox model calculates the electric power as a function of the input hydrogen mass flow rate. It also returns the thermo-physical properties, compositions, and mass flow rates of air, purge, exhaust, and coolants mass flows. (a) Hydrogen inlet

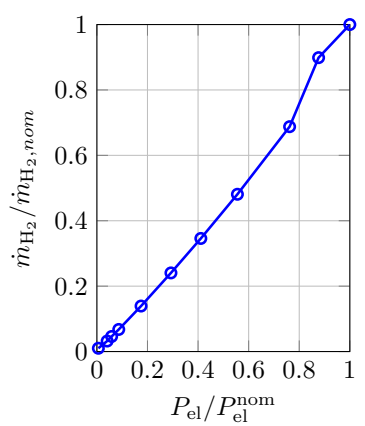

(c) Coolant mass flow

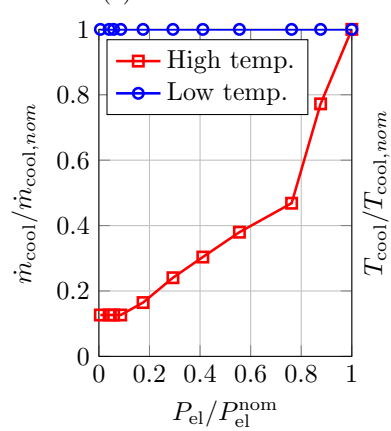

(b) Air inlet

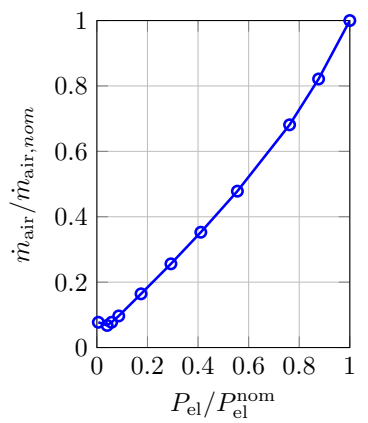

(d) High $T$ coolant temperature

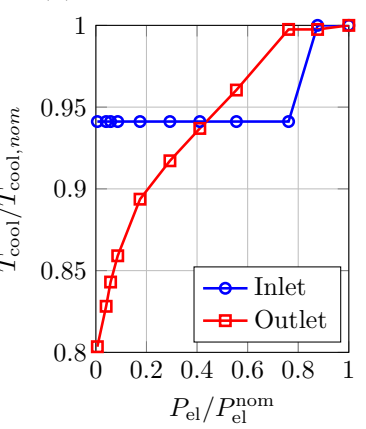

Figure 9: Experimental performance of the automotive derivative PEMFC system. Data are reported in a non-dimensional form.

Note that in Figure 9(d) each temperature profile is normalized with respect to its nominal value. As a con- 
sequence, despite normalized inlet temperature is lower than normalized outlet, the physical values are coherent (i.e. outlet lower than inlet).

\subsection{Pressure Swing Adsorption Separator}

The PSA is modeled with a black box phenomenological approach. The utilized experimental data are reported in Figure 10. The separation efficiency varies

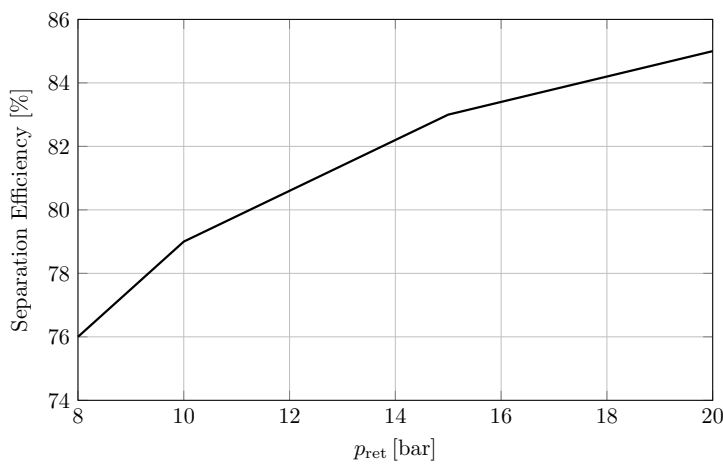

Figure 10: Experimental data for the pressure swing adsorption separator: separation efficiency is expressed as a function of the feed pressure.

between $76 \%$ and $85 \%$, respectively at 8 bar and 20 bar syngas feed pressure, $p_{\text {ret }}$.

The black-box model calculates composition, mass flow rate and pressure of the pure hydrogen and retentate flows, taking as input such characteristics of the syngas.

\section{Case Studies}

Table 1 summarizes the considered power plant configurations. Note that each plant has a different natural gas mass flow rate to obtain the same $\mathrm{H}_{2}$ mass flow rate entering the FC. In this way, the comparison is not biased by the FC efficiency, which is a function of its $\mathrm{H}_{2}$ input mass flow rate, or equivalently of the set-point, as evidenced in Figure 9

\subsection{Plant A: Baseline Plant}

Plant A, schematically reported in Figure 11, is the baseline configuration.

At $\Phi=1,10.4 \mathrm{~kg} / \mathrm{h}$ of $\mathrm{NG}$ are compressed to 12 bar and mixed with $38.7 \mathrm{~kg} / \mathrm{h}$ of super-heated steam at a temperature of $457^{\circ} \mathrm{C}$. The ratio between the mass flow rates of the $\mathrm{NG}$ and of the steam entering the reformer is fixed to $\psi=3.73$. The resulting mixture, at a temperature of $399^{\circ} \mathrm{C}$, is further heated in $\mathrm{HE}-3$ to $760{ }^{\circ} \mathrm{C}$. Such a temperature is the minimum possible to avoid
Table 1: Summary of the considered fule processor configurations

\begin{tabular}{clc}
\hline Case & Description & $\dot{m}_{\mathrm{NG}}^{\mathrm{REF}}+\dot{m}_{\mathrm{NG}}^{\mathrm{BURN}}[\mathrm{kg} / \mathrm{h}]$ \\
\hline Plant A & $\begin{array}{l}\text { Steam reforming, wa- } \\
\text { ter gas shift, purifica- } \\
\text { tion via PSA }\end{array}$ & $10.4+0.204$ \\
\hline Plant B & $\begin{array}{l}\text { Steam reforming, wa- } \\
\text { ter gas shift, purifi- }\end{array}$ & \\
& $\begin{array}{l}\text { cation via selective } \\
\text { membranes }\end{array}$ \\
\hline Plant C & $\begin{array}{l}\text { Steam reforming, } \\
\text { membrane integrated }\end{array}$ & \\
& water gas shift & \\
\hline Plant D & Membrane integrated & $6.21+0.868$ \\
& steam reforming & \\
\hline
\end{tabular}

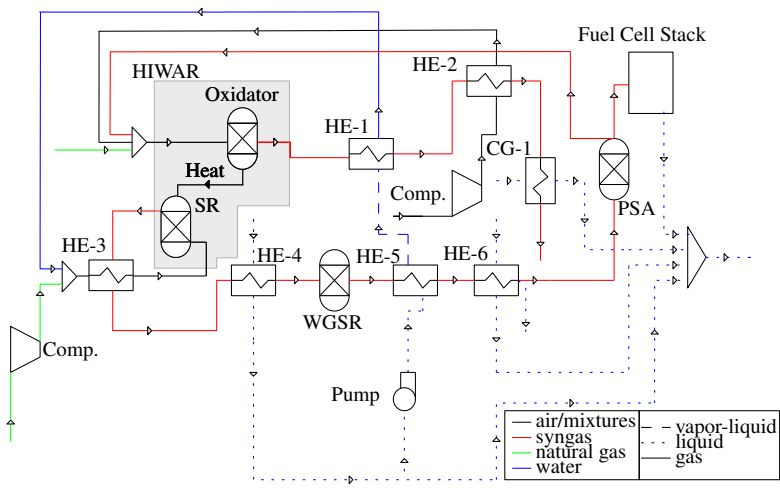

Figure 11: Schematic overview of the baseline energy conversion plant.

an efficiency drop of the reaction [24, 72]. In the same heat exchanger the syngas temperature is reduced from $770{ }^{\circ} \mathrm{C}$ to $436{ }^{\circ} \mathrm{C}$. The working pressure is imposed as a trade-off between the reaction performance [43, 59] and the PSA efficiency (see Figure 10).

In HE-4 the syngas is further cooled to $320^{\circ} \mathrm{C}$, in order to have a favorable water gas shift reaction kinetics. The thermal power extracted from the hydrogen rich gas in HE-4 is used for co-generation. The syngas exits the WGSR at $381{ }^{\circ} \mathrm{C}$, being the $\mathrm{CO}$ shift an exothermic reaction. The thermal energy still present in the $\mathrm{H}_{2}$ rich gas is used both to pre-heat the water necessary for the reforming reaction and for co-generation purposes. Specifically, in $\mathrm{HE}-5$ the water is heated from $15.0^{\circ} \mathrm{C}$ to $188^{\circ} \mathrm{C}$ with a vapour fration of 0.25 , while the syngas is cooled to $128^{\circ} \mathrm{C}$.

The hydrogen rich gas is further cooled to $50^{\circ} \mathrm{C}$ for 
co-generation purposes in HE-6. The gas mixture is then purified in the PSA section and a flux of pure hydrogen is separated to be used in the fuel cell. The rest of the syngas is used in the burner side of the HIWAR reactor (see section 3.2) together with air and natural gas.

The combustion reaction occurs at $845^{\circ} \mathrm{C}$ and at ambient pressure and $0.204 \mathrm{~kg} / \mathrm{h}$ of NG are burned in the oxidator to guarantee the thermal equilibrium of the HIWAR. The total NG mass flow rate is $10.6 \mathrm{~kg} / \mathrm{h}$ (see Table 1p yielding $3.09 \mathrm{~kg} / \mathrm{h}$ of pure $\mathrm{H}_{2}$, that generates $50 \mathrm{~kW}_{\mathrm{el}}$ of net electrical power in the FC. In HE-1 the mixture of water and steam exiting HE-5 is heated at $457^{\circ} \mathrm{C}$ and the flue gases are cooled down from $845^{\circ} \mathrm{C}$ to $198^{\circ} \mathrm{C}$. Subsequently in HE-2 the combustion products are further cooled to $101^{\circ} \mathrm{C}$. As a consequence, the air temperature rises to $188^{\circ} \mathrm{C}$. Finally flue gases are left to the environment at $75^{\circ} \mathrm{C}$ after a co-generative heat recovery.

The mass flow rate of the hot water produced in CG1, HE-6 and HE-4 is determined such that its temperature $T_{\mathrm{COG}}=99^{\circ} \mathrm{C}$. The resulting overall hot water mass flow rate is $246 \mathrm{~kg} / \mathrm{h}$. Thereof, the cogenerated power is $82.5 \mathrm{~kW}_{\text {th }}$, including $68.3 \mathrm{~kW}_{\text {th }}$ from the fuel cell.

Concentrated pressure drops are considered in several elements of the fuel processing plant. Specifically, the pressure drop is reduced by: (i) 0.100 bar in the reformer, (ii) 0.050 bar in both hot and cold side of HE-3, (iii) 0.010 bar in HE-4, (iv) 0.250 bar in the water gas shift reactor, (v) 0.030 bar in HE-1, HE-5 and HE-6, (vi) 0.020 bar in HE-2.

We underline that such a CHP power plant has been already studied in a previous work of the authors [38], however in this case we refine the thermal integration of the components and we implement the accurate modeling approach for heat exchangers described in section 3.5

We determine the part load efficiency of plant A by reducing $\dot{m}_{\mathrm{NG}}^{\text {ref }}$ to $5.19 \mathrm{~kg} / \mathrm{h}$. A further reduction is hindered by the PSA. Figure 12 reports $\eta_{\text {glob }}$ and $\eta_{\text {th }}$ as function of $\Phi$.

The overall electrical efficiency varies between $35.0 \%$ and $40.0 \%$, as a function of $\Phi$, being higher at part load. This is a typical feature of CHP plants based on fuel cells [22, 24, 38]. Such a behavior is dominated by the efficiency curve of the FC [22,-24, 38].

The shadowed region in the plot (Figure 12(a)) is obtained considering two limit cases. For the upper curve, NG comes from the distribution grid already at the working pressure of 12 bar. For the lower curve, the natural gas is distributed at 1 bar and has to be compressed to 12 bar within the power plant. In real cases
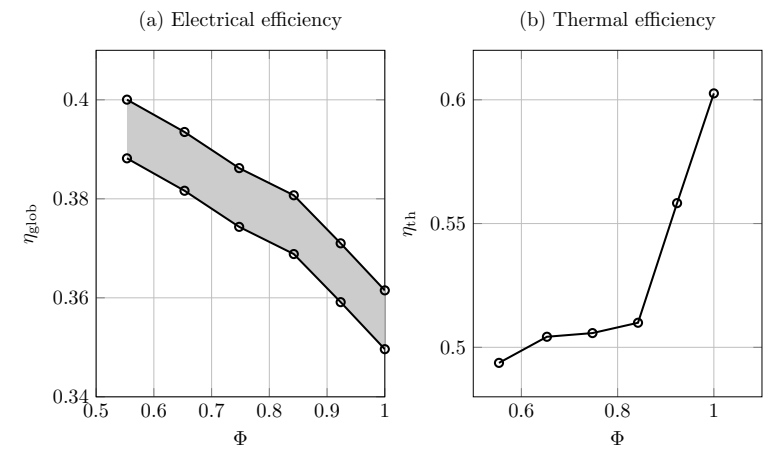

Figure 12: Efficiency of the baseline power plant (Plant A) as a function of $\Phi$ : (a) overall electrical efficiency; (b) thermal efficiency. The shaded band between the two lines in graph (a) identifies the performance with and without including the work needed to compress the natural gas at the fuel processor inlet.

NG will be delivered with a pressure between 1 bar and 12 bar, and the real efficiency will be somewhere in the shadowed area. The efficiency difference between the upper and the lower curve is always $1.19 \%$.

The presence of auxiliary elements has a huge impact on the CHP efficiency. Specifically, in design conditions, the energy consumption of the natural gas compressor and of the other auxiliaries of the fuel processing plant are respectively $3.24 \%$ and $1.43 \%$ of the nominal fuel cell electric power.

Thermal efficiency (see Figure 12 (b)) varies between $49.4 \%$ and $60.2 \%$. The higher $\Phi$, the higher is $\eta_{\text {th }}$, as a consequence of the fuel cell performance variation from part to full load operations. The rapid change in slope of the thermal efficiency curve at $\Phi=84.2 \%$ is probably due to the increasing relevance of the gas transport losses [22-24]. Such a statement is validated also looking at the sudden increment in the coolant mass flow rate for $\Phi>80.0 \%$ shown in Figure 9

\subsection{Plant B: Membrane Separator}

Plant B is schematically depicted in Figure 13

The fuel processing plant is similar to Plant A (see section 4.1). The main difference is that the PSA is replaced by a selective membrane. The membrane unit in Figure 13 is modeled according to the approach described in section 3.1. Pure $\mathrm{H}_{2}$ is released at $1.20 \mathrm{bar}$ and compressed to 2.00 bar to be utilized in the fuel cell. The required membrane area to obtain $y_{\mathrm{H}_{2}}=1.05 y_{\mathrm{H}_{2}}^{\min }$ in nominal conditions and considering $K_{\mathrm{H}_{2}}=8.5 \times$ $10^{-3} \mathrm{~mol} /\left(\mathrm{m}^{2} \mathrm{sPa}^{0.5}\right)$ is $A_{\mathrm{memb}}^{\mathrm{SEP}}=0.286 \mathrm{~m}^{2}$. The resulting separation efficiency of the membrane is $80.3 \%$.

The working pressure of the reformer is kept to 12 bar. Thus, the reaction performance is not significantly 


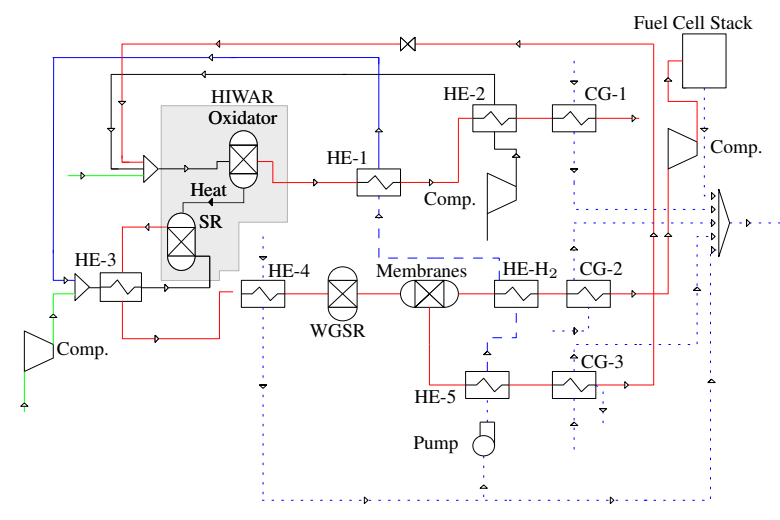

Figure 13: Schematic overview of the energy conversion plant with a membrane separator.

varied [43, 59], while the membrane efficiency (maintaining permeate conditions at 1.20 bar) is similar to the PSA ones (see section 4.2, specifically Figure 4).

In this plant configuration, the hydrogen production system is more efficient than in Plant A. In fact, in Plant $\mathrm{B}$ it is possible to produce the same mass flow of hydrogen, using $9.13 \%$ less natural gas in the reformer. However in the last case the NG mass flow rate required in the burner is 4.34 times the amount registered in Plant A case. This is due to the lower amount of hydrogen in the retentate, that requires to integrate the overall thermal balance with additional chemical energy.
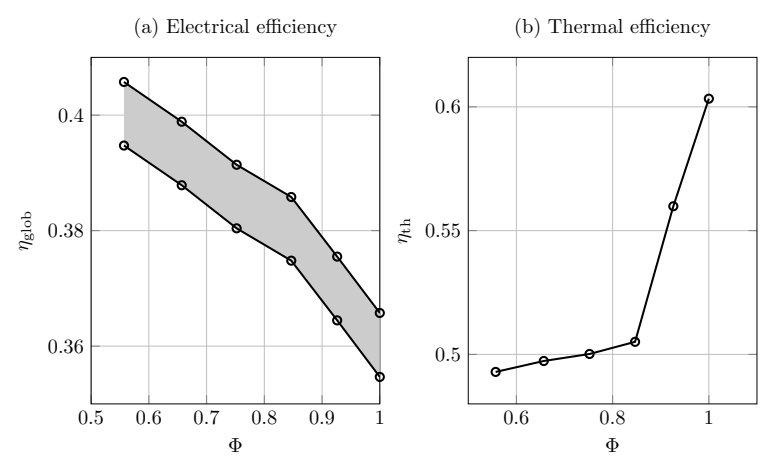

Figure 14: Efficiency of the membrane separator power plant (Plant B) as a function of $\Phi$ : (a) overall electrical efficiency; (b) thermal efficiency. The shaded band between the two lines in graph (a) identifies the performance with and without including the work needed to compress the natural gas at the fuel processor inlet.

The overall electrical efficiency varies between $35.5 \%$ and $40.5 \%$, while $49.3 \%<\eta_{\text {th }}<59.8 \%$, as evidence in Figure 14.

The impact of the auxiliaries is pivotal also in this case. In fact, the energy consumption of the natural gas compressor and of the other auxiliaries of the fuel processing plant are $2.95 \%$ and $1.30 \%$ of $P_{\mathrm{el}}^{\text {nom }}$, respectively. Note that also the $\mathrm{H}_{2}$ compressor has a relevant impact on $\eta_{\text {glob }}$. In fact, its power consumption is $1.38 \%$ of $P_{\mathrm{el}}^{\text {nom }}$.

\subsection{Plant C: Water Gas Shift Membrane Reactor}

The water gas shift membrane reactor power plant is reported (Figure 15).

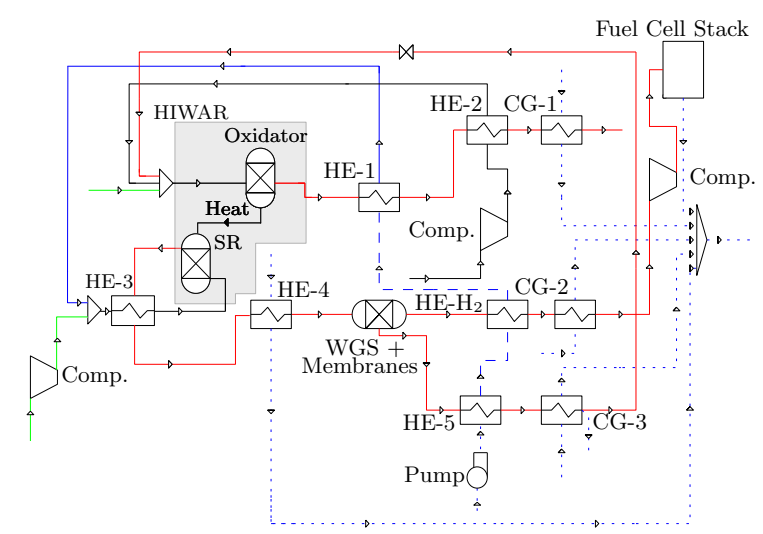

Figure 15: Schematic overview of the energy conversion plant with a water gas shift membrane reactor.

In this configuration hydrogen purification takes place directly in the water gas shift reactor. Thus, the purification section downstream is not necessary anymore, leading to a significant plant simplification. The membrane separator integration in the WGS reactor is performed following the approach illustrated in section 3.4 .

The water required by the steam reforming is first preheated in HE-5, reducing the retentate gas temperature, and then in $\mathrm{HE}-\mathrm{H}_{2}$ reducing the temperature of the pure $\mathrm{H}_{2}$. Similarly, the water of the co-generation circuit first exchanges heat with retentate gases (CG-2) and then with pure $\mathrm{H}_{2}$ (CG-3).

The WGS reactor is operated at 12 bar, wich is the optimal trade off between hydrogen separation and auxiliaries work [43].

The membrane surface necessary to achieve $y_{\mathrm{H}_{2}}=$ $1.05 y_{\mathrm{H}_{2}}^{\min }$ is $A_{\mathrm{memb}}^{\mathrm{WGS}}=0.260 \mathrm{~m}^{2}$, considering $K_{\mathrm{H}_{2}}=8.5 \times$ $10^{-3} \mathrm{~mol} /\left(\mathrm{m}^{2} \mathrm{sPa}^{0.5}\right)$. The resulting $\dot{m}_{\mathrm{H}_{2}}$ is $99.0 \%$ of the one obtainable with an infinite surface reactor, given the initial syngas conditions.

In this case $10.1 \mathrm{~kg} / \mathrm{h}$ of $\mathrm{NG}$ are required to obtain $50 \mathrm{~kW}_{\mathrm{el}}$ of nominal net electrical power from the $\mathrm{FC}$, or, equivalently, $3.09 \mathrm{~kg} / \mathrm{h}$ of pure $\mathrm{H}_{2}$. Membranes shift the equiliblium of reaction (10) towards $\mathrm{H}_{2}$. Thereafter, the CO concentration in the tail gases is $0.498 \%$. 
Such a value is considerably lower compared to Case A $(3.20 \%)$ and B $(2.90 \%)$.
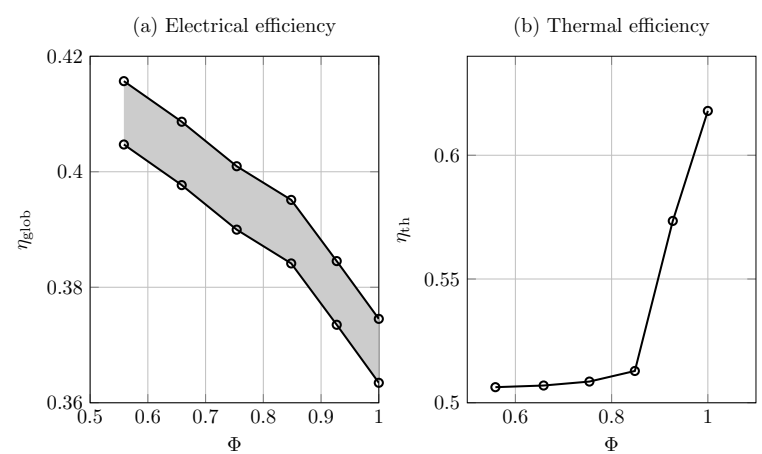

Figure 16: Efficiency of the water gas shift membrane reactor power plant (Plant C) as a function of $\Phi$ : (a) overall electrical efficiency; (b) thermal efficiency. The shaded band between the two lines in graph (a) identifies the performance with and without including the work needed to compress the natural gas at the fuel processor inlet.

The global electrical efficiency varies between a minimum of $36.3 \%$ and a maximum of $41.6 \%$, as evidenced in Figure 16.

The thermal efficiency (see Figure 16 (b)) is comprised between $50.6 \%$ and $61.8 \%$.

\subsection{Plant D: Reforming Membrane Reactor}

Figure 17 represents configuration D. In this case,

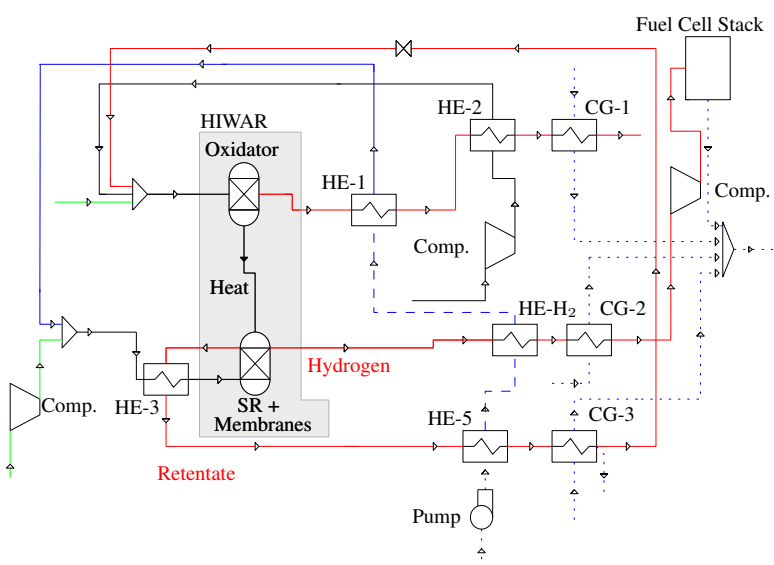

Figure 17: Schematic overview of the energy conversion plant with a reforming membrane reactor.

the membranes are integrated directly in the steam reforming side of the HIWAR reactor, making the water gas shift reactor unnecessary. Note that only $\mathrm{H}_{2}$ is drained by the membrane shifting the equilibrium of reaction (10)(b) towards the products. As a consequence the CO mass flow rate in the retentate is just $1.68 \%$ of the total pure hydrogen produced, much lower than $3.20 \%$ and $2.94 \%$ observed for plants A and B, respectively. On the contrary, the $\mathrm{CO}$ concentration in the retentate is higher than that observed for plant $\mathrm{C}$ due to the lower temperature of the shift reactor, compared to the reformer.

Note that the membrane separator integration in the steam reforming reactor is performed according to the approach illustrated in section 3.4

The working pressure of the reformer is set to 35 bar. Such an assumption is justified by the sensitivity analysis reported in section 5.1

The surface of the selective membrane required to obtain $y_{\mathrm{H}_{2}}=1.05 y_{\mathrm{H}_{2}}^{\min }$ is $A_{\mathrm{memb}}^{\mathrm{REF}}=0.250 \mathrm{~m}^{2}$, considering $K_{\mathrm{H}_{2}}=8.5 \times 10^{-3} \mathrm{~mol} /\left(\mathrm{m}^{2} \mathrm{sPa}^{0.5}\right)$. We use here the same permeance value of the other plant configurations. However, the relatively high temperature of the reformer reactor (i.e. $770{ }^{\circ} \mathrm{C}$ ) would result in a higher $K_{\mathrm{H}_{2}}$ and, as a consequence, a lower membrane surface for the same performance. Such aspect would lower the cost of the energy system, that here is not investigated in detail.

The range of the possible set-points in cases A, B, $\mathrm{C}$ is limited around $60.0 \%$ by PSA and reformer constraints of the real fuel processing plant under construction within the European project [32]. However, in this case the fuel converter is completely different in the construction, so we cannot determine a priori the minimum possible set-point. For this reason the sensitivity analysis is performed for a wider operating range (see Figure 18. The value of the natural gas mass flow rate entering the power plant, in design conditions, is, in this case, $\dot{m}_{\mathrm{NG}}^{\mathrm{REF}}+\dot{m}_{\mathrm{NG}}^{\mathrm{BURN}}=9.52 \mathrm{~kg} / \mathrm{h}$.
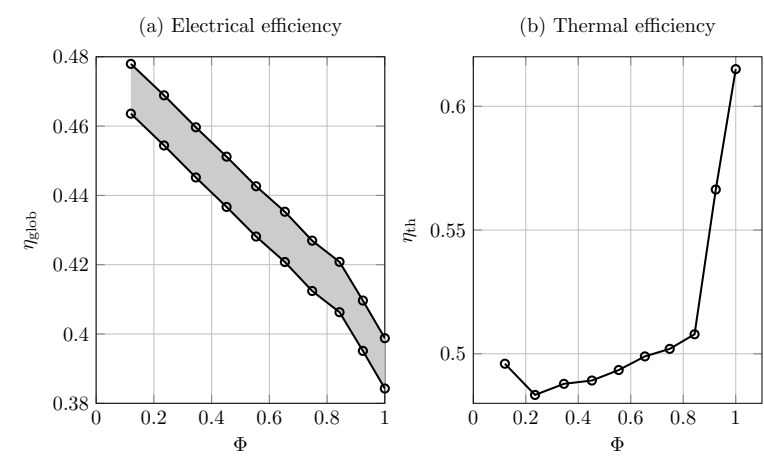

Figure 18: Efficiency of the reforming membrane reactor power plant (Plant D) as a function of $\Phi$ : (a) overall electrical efficiency; (b) thermal efficiency. The shaded band between the two lines in graph (a) identifies the performance with and without including the work needed to compress the natural gas at the fuel processor inlet. 
The global electric efficiency of the power plant varies between $38.4 \%$ and $47.8 \%$, being the highest of all analyzed configurations, as represented in Figure 18 (a).

The thermal efficiency increases by increasing $\Phi$ as evidenced in Figure 18(b), mainly because the FC operation is less efficient (degradating more chemical energy into heat). In particular, $\eta_{\text {th }}$ varies in the range $[49.6 \%, 61.5 \%]$. The sharp change of slope for setpoints $\Phi<12.0 \%$ is probably due to the fuel processor efficiency drop in such a region (see Figure 19.a)).

\section{Discussion}

A comparison between the results obtained in all the configurations previously presented is now performed. The efficiency values for each power plant, for $\Phi=1$, are reported in table 2 .

Table 2: Efficiency values in nominal conditions for each power plant analyzed.

\begin{tabular}{lccc}
\hline Case & $\eta_{\text {fp }}[\%]$ & $\eta_{\text {glob }}[\%]$ & $\eta_{\text {th }}[\%]$ \\
\hline Plant A & 75.1 & 35.0 & 60.3 \\
Plant B & 77.0 & 35.5 & 60.3 \\
Plant C & 78.7 & 36.3 & 61.8 \\
Plant D & 83.8 & 38.4 & 61.5 \\
\hline
\end{tabular}

Figure 19 reports the relevant performance of the power plant as functions of the set-point.

The fuel processor efficiency has almost a flat response to the load condition. The average values are $\eta_{\mathrm{fp}}=75.1 \%, \eta_{\mathrm{fp}}=77.0 \%, \eta_{\mathrm{fp}}=78.8 \%, \eta_{\mathrm{fp}}=$ $83.7 \%$, respectively for Plant A, B, C and D. Rearranging eqs. (1), and (2) and defining the fuel cell efficiency as:

$$
\eta_{\mathrm{FC}}=\frac{P_{\mathrm{el}}}{\dot{m}_{\mathrm{H}_{2}} \mathrm{LHV}_{\mathrm{H}_{2}}}
$$

we can write the following equation for the fuel processor efficiency:

$$
\eta_{\mathrm{fp}}=\frac{\eta_{\mathrm{glob}}}{\eta_{\mathrm{FC}}}+\frac{W_{\mathrm{aux}}^{\mathrm{ref}}}{\dot{m}_{\mathrm{NG}} \mathrm{LHV}_{\mathrm{NG}} \eta_{\mathrm{FC}}} .
$$

Considering the target $\eta_{\mathrm{glob}}=0.420$, and a mean $\eta_{\mathrm{FC}}=0.500$ and $W_{\mathrm{aux}}^{\mathrm{ref}} / \dot{m}_{\mathrm{NG}} \mathrm{LHV}_{\mathrm{NG}}=0.0191$ we get $\eta_{\mathrm{fp}}=0.878$. Such an efficiency of the fuel processor should be reached in nominal conditions to attend the FCH-JU [31] goal.

The most relevant parameter is $\eta_{\text {glob }}$ that, at nominal conditions, increases by $9.71 \%$ (i.e. from $35.0 \%$ to
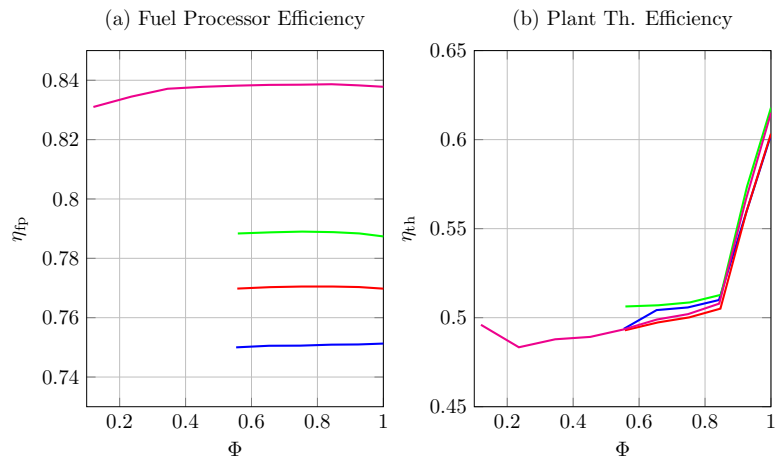

(c) Plant El. Efficiency

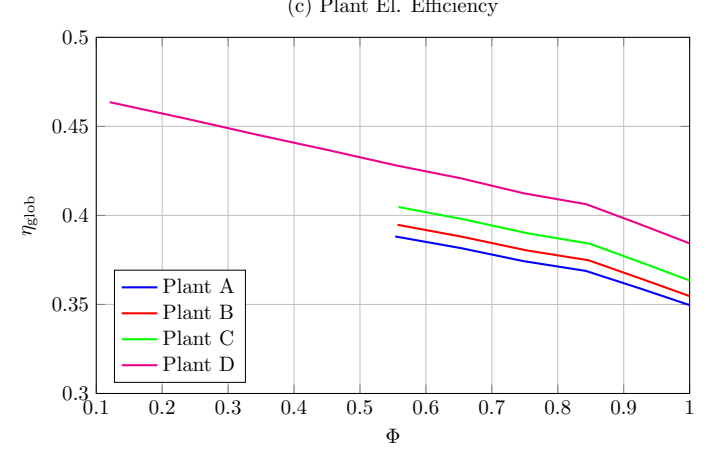

Figure 19: Performance of the considered power plants as functions of $\Phi$ : (a) fuel processor efficiency; (b) plant thermal efficiency; (c) plant minimun electric efficiency (natural gas from the grid at 1 bar).

$38.4 \%$ ) switching from Plant A to Plant D. This is possible mainly for two reasons: (i) shift of the reforming reaction towards products; (ii) better thermal integration for heat recovery in the reacting fluxes. The target for the overall plant electric efficiency set by the FCHJU [31] is $42.0 \%$, Plant D configuration meets such a prescription for $\Phi<65 \%$. However, in a real energy management scenario, the plant set-point will rarely be 1 , making the effective electrical efficiency supposedly higher than the target. Moreover, configurations aiming at increasing the energy converter efficiency can be adopted, like for example the usage of two fuel cells of nominal power $50 \mathrm{~kW}_{\mathrm{el}}$ in parallel downstream the fuel processor to improve the FC electrical efficiency [38].

We note that configurations $\mathrm{B}$ and $\mathrm{C}$ significantly reduce the fuel processor complexity with respect to the baseline configuration A by eliminating the semi-batch PSA process. However, their impact on the system efficiency is minor compared to configuration D.

In fact, only the integration of the membrane within the HIWAR promotes an effective shift of the equilibrium reactions towards $\mathrm{H}_{2}$ production. Moreover, it significantly improves the thermal integration of the fuel processor components by avoiding the cooling process 
to $320^{\circ} \mathrm{C}$, necessary for water gas shift reaction, before thermal recovery.

Thereafter, in the following sections we further dissect the power plant $\mathrm{D}$ by systematically varying the important operating parameters (i.e. pressure, applied membrane surface, reformer temperature and pinch point of the heat exchangers). The aim is to establish the most convenient working parameters, considering thermodynamic performance as well as technological and economic aspects.

\subsection{Effects of the Reformer Pressure and of the Mem- brane Surface}

We study the effect of the reformer pressure, in order to establish the optimal operating conditions for configuration D. In fact, literature data are available for the simple reforming reaction [43, 59]. The presence of hydrogen separation through selective membranes, that is a function of the pressure gradient, might change the optimal operating conditions. In addition a sensitivity analysis to the applied membrane surface area is performed. Results for $\dot{m}_{\mathrm{NG}}^{\mathrm{REF}}=6.90 \mathrm{~kg} / \mathrm{h}$, and considering $K_{\mathrm{H}_{2}}=8.5 \times 10^{-3} \mathrm{~mol} /\left(\mathrm{m}^{2} \mathrm{sPa}^{0.5}\right)$, are reported in Figure 20 The power required from the auxiliaries is evaluated assuming the natural gas coming from the grid at 1 bar

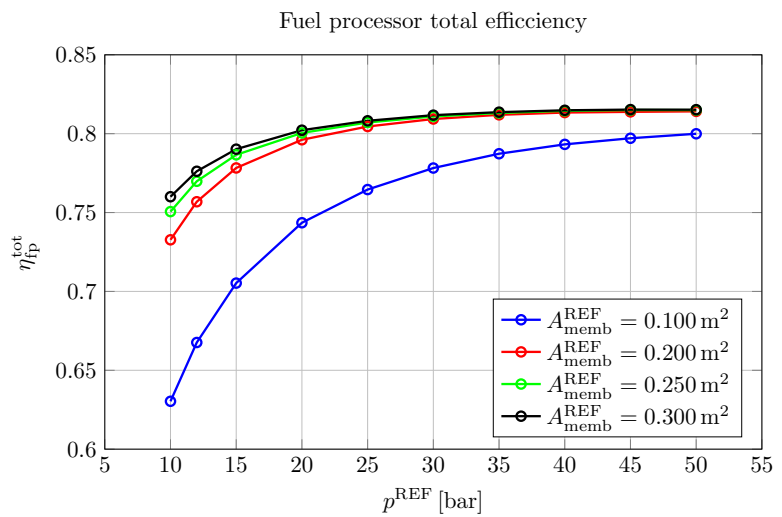

Figure 20: Fuel processor efficiency as a function of the pressure $p^{\mathrm{REF}}$, and of the applied membrane surface area $A_{\mathrm{memb}}^{\mathrm{REF}}$. The power required from the auxiliaries is evaluated considering the natural gas coming from the grid a 1 bar.

We note, from Figure 20, that $\eta_{\mathrm{fp}}^{\text {tot }}$ varies in the range [63.0\%-81.5\%], as a function of the reformer pressure and of the applied membrane surface area. In fact, the fuel processor total efficiency increases augmenting such parameters. However, we also note a saturation in the performance increase. We consider in this analysis the fuel processor total efficiency $\eta_{\mathrm{fp}}^{\text {tot }}$, defined in eq (3), in order to take into account the effects of the pressure rise in the work required by the auxiliaries. Summarizing, $A_{\mathrm{memb}}^{\mathrm{REF}}=0.250 \mathrm{~m}^{2}$ and $p^{\mathrm{REF}}=35.0$ bar shoud be considered as a techno-economic compromise. In fact, decreasing these two values results in a decrement of the performance. On the other hand, further increasing them is unnecessary because the efficiency improvement would be marginal and would not compensate the higher cost of the overall energy plant.

For $p^{\mathrm{REF}}>30$ bar and $A_{\mathrm{memb}}^{\mathrm{REF}} \geq 0.200 \mathrm{~m}^{2}$ the efficiency curves collapse. Nevertheless, Figure 20 evidences that, when the membrane surface is too small (e.g. $\left.0.100 \mathrm{~m}^{2}\right) \eta_{\mathrm{fp}}^{\text {tot }}$ is significantly lower compared to the other cases, even for $p^{\mathrm{REF}}=50.0 \mathrm{bar}$.

\subsection{Reforming Temperature Analysis}

The temperature of the membrane reforming reactor strongly affects the membrane stability [37] and the plant performance [24, 72]. For stability purposes it should be relatively low, while higher $T^{\mathrm{REF}}$ might improve the reformer performance. For this reason, $\eta_{\mathrm{fp}}$ is estimated varying $T^{\mathrm{REF}}$ in the range $\left[590^{\circ} \mathrm{C}\right.$, $\left.850^{\circ} \mathrm{C}\right]$. The results reported in Figure 21 are retrieved for $\dot{m}_{\mathrm{NG}}^{\mathrm{REF}}=6.90 \mathrm{~kg} / \mathrm{h}$.

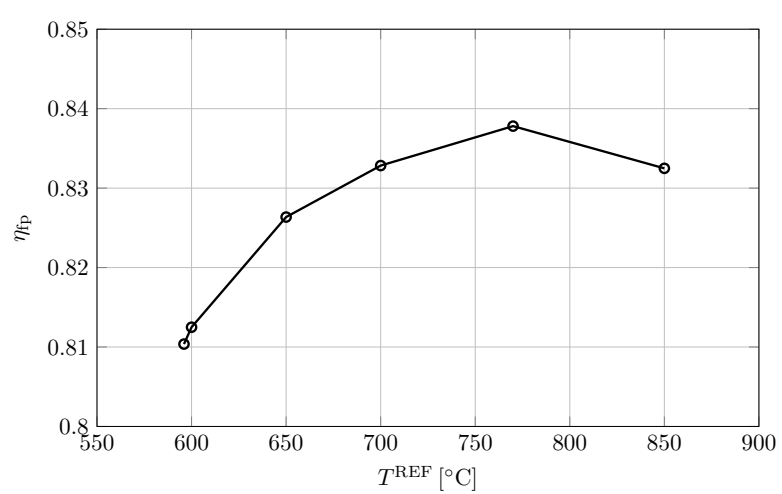

Figure 21: Fuel processor efficiency as a function of the reformer temperature $\left(T^{\mathrm{REF}}\right)$.

We comment that, for a reforming temperature $T^{\mathrm{REF}}=600^{\circ} \mathrm{C}$, the chemical energy present in the retentate (in the form of un-reacted natural gas and non separated hydrogen) is enough to provide the thermal power necessary for the reforming, without providing additional NG to the burner. As a consequence the system in study cannot be operated at $T^{\mathrm{REF}}<600^{\circ} \mathrm{C}$, otherwise some chemical energy in the retentate should be wasted, leading to a dramatical decrease in the efficiency of the fuel processor.

For $\dot{m}_{\mathrm{NG}}^{\mathrm{REF}}=6.90 \mathrm{~kg} / \mathrm{h}$, the pure hydrogen mass flow rate produced varies between $\dot{m}_{\mathrm{H}_{2}}=3.09 \mathrm{~kg} / \mathrm{h}$ for a reformer temperature of $770{ }^{\circ} \mathrm{C}$, and $\dot{m}_{\mathrm{H}_{2}}=2.22 \mathrm{~kg} / \mathrm{h}$ for 
a reformer temperature of $600{ }^{\circ} \mathrm{C}$. Thereafter, lowering the temperature reduces the system power density. Moreover, $\eta_{\text {fp }}$ decreases from $83.8 \%$ to $81.2 \%$ by reducing $T^{\mathrm{REF}}$ from $770{ }^{\circ} \mathrm{C}$ to $600^{\circ} \mathrm{C}$. Such a performance derating might be acceptable if necessary to use selective membranes integrated in the steam reforming reactor.

A drop in the fuel processor efficiency is observed, from Figure 21, for $T^{\mathrm{REF}}=850^{\circ} \mathrm{C}$. In fact, while the yield of reaction $(10)$ is almost constant for temperatures higher than $770{ }^{\circ} \mathrm{C}$, the thermal power necessary to sustain the process increases. As a consequence the natural gas send to the burner increases, while the pure hydrogen produced remains almost constant.

\subsection{Pinch Point Analysis}

The thermal integration in an endothermic process, such as the production of hydrogen via natural gas steam reforming, is a key aspect to obtain a good efficiency of the fuel conversion. For this reason, the heat exchangers for thermal energy recovery in the fuel processor are crucial elements. In fact, decreasing the pinch point temperature difference would result in a better exploitation of the thermal power available in the hot fluxes. However, such a process entails increasing the cost of the heat exchanger. For this reason, it is interesting to assess the impact of the pinch point temperature difference, of all heat exchangers in the plant, on the efficiency of the fuel processor. The results of such analysis are reported in Figure 22

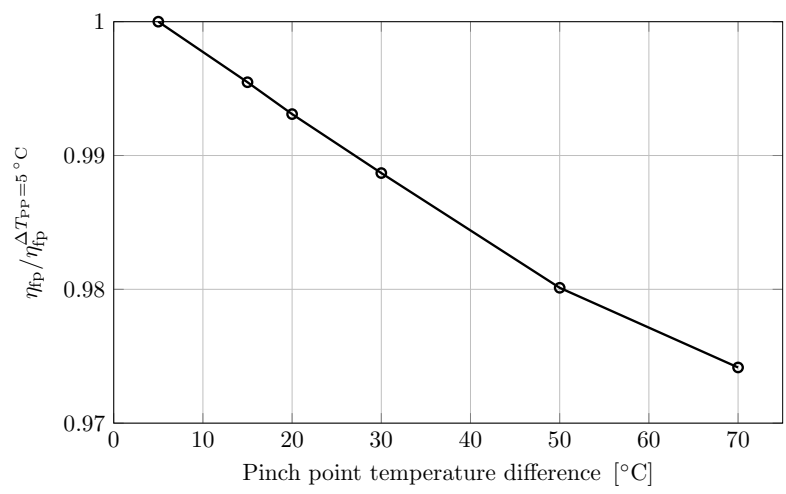

Figure 22: Ratio between the fuel processor efficiency and $\eta_{\mathrm{fp}}$ calculated for a pinch point temperature difference of $5^{\circ} \mathrm{C}$, as a function of the pinch point temperature difference of all heat exchangers in the fuel processor.

Figure 22 shows that a significant correlation between the pinch point temperature difference and the fuel processor efficiency is not present. In fact, $\eta_{\text {fp }}$ decreases only by $3 \%$ by increasing $\Delta T_{\mathrm{PP}}$ from $5^{\circ} \mathrm{C}$ to $70^{\circ} \mathrm{C}$.

\section{Conclusions}

In this paper we assess the effects of the integration of Pd-based selective membranes in the fuel processor of a $50 \mathrm{~kW}_{\mathrm{el}}$ PEMFC based CHP system, fed by natural gas. Specifically, we evaluate the following performance indicators: (i) the overall electric efficiency, (ii) the fuel processor efficiency, (iii) and the thermal efficiency. Both design and off-design operating conditions are considered. We use a quasi-lumped parameter approach, integrating Aspen Plus ${ }^{\circledR}$ with physical and phenomenological models. We systematically study the integration of selective membranes in the fuel processor, through four case studies. First, we evaluate the performance of a baseline plant, that accounts for steam reforming, water gas shift and syngas purification via pressure swing adsorption unit. Such a system represents the state of the art of PEMFC CHP systems fueled with natural gas. Then, we assess the integration of Pd-based selective membranes as purification unit and integrated both in the water gas shift reactor and in the steam reforming unit. Moreover, detailed analyses are performed on the working parameters, such as the reactors pressure and temperature together with selective membranes surface, of the most innovative fuel processing plant configuration.

The results show that the usage of selective membranes can boost the power plant efficiency. Specifically, the fuel processor nominal efficiency increases from $75.1 \%$, for the baseline configuration, to $83.8 \%$, for the fuel processing plant with selective membranes integrated in the steam reformer. As a consequence, the overall electrical efficiency rises from $35.0 \%$ to $38.4 \%$. This is mainly due the shift of the reforming reaction towards products and to the better thermal integration for heat recovery in reacting fluxes. However, when selective membranes are used as separator or integrated in the water gas shift reactor, the performance boost is minor. In addition, the necessary membrane surface, that largely determine the power plant cost, decreases if the separator is integrated in the reactors. The minimum value of selective membrane area is reached for Plant D configuration, which integrates the membranes into the steam reformer reactor. The real convenience of the improved energy systems studied should be assessed in a real energy management scenario, to thoroughly evaluate the economical and environmental benefits associated to the improved efficiency.

The integration of Pd-based selective membranes leads also to an important fuel processing plant simplification, in particular when the reforming membrane reactor configuration is considered. 
At part load, similar conclusions can be made. In fact, the fuel processor efficiency is insensitive to the setpoint, while the overall electrical efficiency increases at part load, due to the FC efficiency curve. The thermal efficiency has the opposite behavior. Such trends could be favorable in a real energy management scenario, where the power plant can be often used in offdesign conditions (thus at higher electrical efficiency) to meet the user requirements.

In addition, when using Pd-selective membranes integrated in the steam reforming reactor, we found that the optimal working pressure for the system is 35 bar, as a compromise between chemical equilibrium, auxiliary power, and membrane separation efficiency.

The membrane surface is also recognized as a limiting factor to performance, if not properly sized. However, an overestimation could lead to unnecessary additional costs. For these reasons an accurate 2-D or 3$\mathrm{D}$ modeling of the Pd-based selective membranes, also when integrated in reactors could be useful. In fact, phenomena such as the boundary layer formation (i.e. concentration polarisation), or the spatial distribution of the selective membranes in a specific geometry should be investigated. Moreover, several effects such as the how the hydrogen permeance of the membrane varies with temperature could be studied.

To facilitate the integration of selective membranes, the steam reforming reactor can be operated at $600{ }^{\circ} \mathrm{C}$ instead of $770{ }^{\circ} \mathrm{C}$, with a fuel processor efficiency decrease of $3.20 \%$. We also comment that for Plant D at $650-700^{\circ} \mathrm{C}$, which is well in the range proposed in [60], $\eta_{\mathrm{fp}}$ is still higher compared to the baseline plant. Thus, significant enhancement of fuel processor performance can be obtained also with the current membrane technology through Plant D. We cannot reduce the reformer temperature below $600{ }^{\circ} \mathrm{C}$, as the chemical energy present in the retentate would be enough to sustain the thermal requirements from the endothermic reactions.

It is also important to note that, according to the state of the art technology, selective membranes made by Pd$\mathrm{Ag}$ alloys can operate in a temperature range of $\left(300^{\circ} \mathrm{C}\right.$ $\left.700^{\circ} \mathrm{C}\right)[60]$. For this reason the technological implementation of Plant D configuration is still questionable. However, from a performance point of view the just cited case is the most relevant, accounting for highest electrical efficiency values. As a consequence, this work focuses on showing the possible advantages related to the selective membranes usage in a CHP energy system, just from the energy performance point of view. Relying on our results we can conclude that the technological development of selective membranes should be directed towards the extension of the range of possible operating temperatures.

Finally, we underline that the absolute value of the hydrogen permeance of the membrane does not influence the efficiency. On the other hand, the permeance value obviously affects the required membrane area for a certain separation, and thus the economics of the concept, which is not investigated in this paper.

\section{Acknowledgment}

This project has received funding from the Fuel Cells and Hydrogen Joint Undertaking under grant agreement $\mathrm{N}^{\circ} 671396$. This Joint Undertaking receives support from the European Unions Horizon 2020 research and innovation program and United Kingdom, Germany, Greece, Croatia, Italy, Switzerland, Norway. Swiss partners are funded by the State Secretariat for Education, Research and Innovation of the Swiss Confederation.

\section{References}

[1] Cabeza, L.F., Urge-Vorsatz, D., McNeil, M.A., Barreneche, C., Serrano, S.. Investigating greenhouse challenge from growing trends of electricity consumption through home appliances in buildings. Renewable and Sustainable Energy Reviews 2014;36:188-193.

[2] Ürge-Vorsatz, D., Cabeza, L.F., Serrano, S., Barreneche, C., Petrichenko, K.. Heating and cooling energy trends and drivers in buildings. Renewable and Sustainable Energy Reviews 2015;41:85-98.

[3] Serrano, S., Ürge-Vorsatz, D., Barreneche, C., Palacios, A., Cabeza, L.F.. Heating and cooling energy trends and drivers in Europe. Energy 2017;119:425-434.

[4] Combined heat and power Evaluating the benefits of greater global investment. International Energy Agency ; 2008.

[5] Chicco, G., Mancarella, P.. Distributed multi-generation: a comprehensive view. Renewable and Sustainable Energy Reviews 2009;13(3):535-551.

[6] Onovwiona, H., Ugursal, V.I.. Residential cogeneration systems: review of the current technology. Renewable and sustainable energy reviews 2006;10(5):389-431.

[7] Distributed Generation in Liberalised Electricity Markets. International Energy Agency ; 2002.

[8] Cozzolino, R., Tribioli, L., Bella, G.. Power management of a hybrid renewable system for artificial islands: A case study. Energy 2016;106:774-789.

[9] Lau, K.Y., Yousof, M., Arshad, S., Anwari, M., Yatim, A.. Performance analysis of hybrid photovoltaic/diesel energy system under Malaysian conditions. Energy 2010;35(8):32453255.

[10] Franco, A., Salza, P.. Strategies for optimal penetration of intermittent renewables in complex energy systems based on technooperational objectives. Renewable Energy 2011;36(2):743-753.

[11] Naqvi, M., Dahlquist, E., Yan, J.. Complementing existing CHP plants using biomass for production of hydrogen and burning the residual gas in a CHP boiler. Biofuels 2017;8(6):675683. 
[12] Ackermann, T., Andersson, G., Söder, L.. Distributed generation: a definition. Electric power systems research 2001;57(3):195-204.

[13] Monthly new residential construcitons. The U.S. Census Bureau and the U.S. Department of Housing and Urban Development; February 2018. URL https://www.census.gov/ construction/nrc/pdf/newresconst.pdf

[14] Cappa, F., Facci, A.L., Ubertini, S.. Proton exchange membrane fuel cell for cooperating households: A convenient combined heat and power solution for residential applications. Energy 2015;90:1229-1238.

[15] Jannelli, E., Minutillo, M., Perna, A.. Analyzing microcogeneration systems based on LT-PEMFC and HT-PEMFC by energy balances. Applied Energy 2013;108:82-91.

[16] Pellegrino, S., Lanzini, A., Leone, P.. Techno-economic and policy requirements for the market-entry of the fuel cell micro-CHP system in the residential sector. Applied Energy 2015;143:370-382.

[17] Adam, A., Fraga, E.S., Brett, D.J.. Options for residential building services design using fuel cell based micro$\mathrm{CHP}$ and the potential for heat integration. Applied Energy 2015;138:685-694.

[18] Calise, F., Figaj, R.D., Massarotti, N., Mauro, A., Vanoli, L.. Polygeneration system based on PEMFC, CPVT and electrolyzer: Dynamic simulation and energetic and economic analysis. Applied Energy 2017;192:530-542.

[19] Jannelli, E., Minutillo, M., Cozzolino, R., Falcucci, G Thermodynamic performance assessment of a small size CCHP (combined cooling heating and power) system with numerical models. Energy 2014;65:240-249.

[20] Sammes, N., Boersma, R.. Small-scale fuel cells for residential applications. Journal of Power sources 2000;86(1-2):98-110.

[21] Onovwiona, H., Ugursal, V.I.. Residential cogeneration systems: review of the current technology. Renewable and Sustainable Energy Reviews 2006;10(5):389-431.

[22] Barbir, F.. PEM fuel cells. In: Fuel Cell Technology. Springer; 2006, p. 27-51.

[23] O'hayre, R., Cha, S.W., Prinz, F.B., Colella, W.. Fuel Cell Fundamentals. John Wiley \& Sons; 2016.

[24] Fuel Cell Handbook, seventh edition, Inc., Albuquerque, NM, DOE/NETL-2004/1206. EG\&G technical services; 2004

[25] Baratto, F., Diwekar, U.M., Manca, D.. Impacts assessment and tradeoffs of fuel cell based auxiliary power units: part II. Environmental and health impacts, LCA, and multi-objective optimization. Journal of power sources 2005;139(1-2):214-222.

[26] Singhal, S.C.. Advances in solid oxide fuel cell technology. Solid State Ionics 2000;135(1-4):305-313.

[27] Sadhukhan, J.. Distributed and micro-generation from biogas and agricultural application of sewage sludge: Comparative environmental performance analysis using life cycle approaches. Applied Energy 2014;122:196-206.

[28] The fuel cell industry review 2013. Tech. Rep.; Fuel Cell Today; 2013. URL http://www.fuelcelltoday.com/media/ 1889744/fct_review_2013.pdf

[29] Hart, D., Lehner, F., Rose, R., Lewis, J., Klippenstein, M. The Fuel Cell Industry Review 2017. Tech. Rep.; E4tech; 2017. URL http: //www . fuelcellindustryreview.com/

[30] Facci, A.L., Ubertini, S.. Analysis of a fuel cell combined heat and power plant under realistic smart management scenarios. Applied Energy 2018;216:60-72.

[31] FUEL CELLS AND HYDROGEN JOINT UNDERTAKING (FCH JU) Multi-Annual Work Plan 2014-2020. 2014 URL http://www.fch.europa.eu/sites/default/ files/documents/FCH2 $\% 20 \mathrm{JU} \% 20-\% 20 \mathrm{Multi} \% 20$ Annual $\%$ 20Work\%20Plan\%20-\%20MAWP_en_0.pdf
[32] CORDIS the Community Research and Development Information Service. European Commission; 2016. URL https: //cordis.europa.eu/project/rcn/197929_en.html

[33] Staffell, I., Green, R.. The cost of domestic fuel cell micro-CHP systems. International Journal of Hydrogen Energy 2013;38(2):1088-1102.

[34] Spendelow, J., Marcinkoski, J., Papageorgopoulos, D.. Micro CHP Fuel Cell System Targets. 2012. URL https://www.hydrogen.energy.gov/pdfs/11016_ micro_chp_target.pdf

[35] James, B.D., Spisak, A.B., Colella, W.G.. Manufacturing Cost Analysis of Stationary Fuel Cell Systems. Tech. Rep.; Strategic Analysis; 2012

[36] Weimar, M.R., Chick, L.A., W, G.D., Whyatt, G.A.. Cost Study for Manufacturing of Solid Oxide Fuel Cell Power Systems. Tech. Rep. PNNL-22732; U.S. Department of Energy; 2012.

[37] Peters, T.A., Bredesen, R., Venvik, H.J.. Pd-based Membranes in Hydrogen Production: Long-term Stability and Contaminant Effects. In: Membrane Engineering for the Treatment of Gases. 2017, p. 177-211.

[38] Facci, A.L., Loreti, G., Ubertini, S., Barbir, F., Chalkidis, T., Eßling, R.P., et al. Numerical assessment of an automotive derivative chp fuel cell system. Energy Procedia 2017;105:1564 -1569 .

[39] Ghasemzadeh, K., Zeynali, R., Basile, A.. Theoretical study of hydrogen production using inorganic membrane reactors during WGS reaction. International Journal of Hydrogen Energy 2016;41(20):8696-8705.

[40] De Falco, M., Capocelli, M., Basile, A.. Selective membrane application for the industrial one-step DME production process fed by $\mathrm{CO} 2$ rich streams: Modeling and simulation. International Journal of Hydrogen Energy 2017;42(10):6771-6786.

[41] Iulianelli, A., Algieri, C., Donato, L., Garofalo, A., Galiano, F., Bagnato, G., et al. New PEEK-WC and PLA membranes for $\mathrm{H} 2$ separation. International Journal of Hydrogen Energy 2017;42(34):22138-22148.

[42] Hiramatsu, H., Sakurai, M., Maki, T., Kameyama, H.. Stacked etched aluminum flow-through membranes for methanol steam reforming. International Journal of Hydrogen Energy 2017;42(15):9922-9929.

[43] Perna, A., Cicconardi, S., Cozzolino, R.. Performance evaluation of a fuel processing system based on membrane reactors technology integrated with a PEMFC stack. International Journal of Hydrogen Energy 2011;36(16):9906-9915.

[44] Roses, L., Manzolini, G., Campanari, S., De Wit, E., Walter, M.. Techno-economic assessment of membrane reactor technologies for pure hydrogen production for fuel cell vehicle fleets. Energy \& Fuels 2013;27(8):4423-4431.

[45] Di Marcoberardino, G., Sosio, F., Manzolini, G., Campanari, S.. Fixed bed membrane reactor for hydrogen production from steam methane reforming: Experimental and modeling approach. International Journal of Hydrogen Energy 2015;40(24):7559-7567.

[46] Di Marcoberardino, G., Roses, L., Manzolini, G.. Technical assessment of a micro-cogeneration system based on polymer electrolyte membrane fuel cell and fluidized bed autothermal reformer. Applied Energy 2016;162:231-244.

[47] Di Marcoberardino, G., Gallucci, F., Manzolini, G., van Sint Annaland, M.. Definition of validated membrane reactor model for $5 \mathrm{~kW}$ power output CHP system for different natural gas compositions. International Journal of Hydrogen Energy 2016;41(42):19141-19153.

[48] Gallucci, F., Paturzo, L., Basile, A.. A simulation study of the steam reforming of methane in a dense tubular membrane reac- 
tor. International Journal of Hydrogen Energy 2004;29(6):611617.

[49] Ghasemzadeh, K., Andalib, E., Basile, A.. Evaluation of dense $\mathrm{Pd}-\mathrm{Ag}$ membrane reactor performance during methanol steam reforming in comparison with autothermal reforming using CFD analysis. International Journal of Hydrogen Energy 2016;41(20):8745-8754.

[50] Iulianelli, A., Ribeirinha, P., Mendes, A., Basile, A.. Methanol steam reforming for hydrogen generation via conventional and membrane reactors: a review. Renewable and Sustainable Energy Reviews 2014;29:355-368.

[51] Kim, C.H., Han, J.Y., Kim, S., Lee, B., Lim, H., Lee, K.Y., et al. Hydrogen production by steam methane reforming in a membrane reactor equipped with a Pd composite membrane deposited on a porous stainless steel. International Journal of Hydrogen Energy 2017;

[52] Kim, C.H., Han, J.Y., Lim, H., Lee, K.Y., Ryi, S.K.. Methane steam reforming using a membrane reactor equipped with a Pdbased composite membrane for effective hydrogen production. International Journal of Hydrogen Energy 2017;

[53] Fedotov, A., Antonov, D., Uvarov, V., Tsodikov, M.. Original hybrid membrane-catalytic reactor for the Co-Production of syngas and ultrapure hydrogen in the processes of dry and steam reforming of methane, ethanol and DME. International Journal of Hydrogen Energy 2018;43(14):7046-7054.

[54] Cruz, B.M., da Silva, J.D.. A two-dimensional mathematical model for the catalytic steam reforming of methane in both conventional fixed-bed and fixed-bed membrane reactors for the production of hydrogen. International Journal of Hydrogen Energy 2017;42(37):23670-23690.

[55] Ma, R., Castro-Dominguez, B., Dixon, A.G., Ma, Y.H.. CFD study of heat and mass transfer in ethanol steam reforming in a catalytic membrane reactor. International Journal of Hydrogen Energy 2017;

[56] Zhang, Y., Lundblad, A., Campana, P.E., Yan, J.. Comparative Study of Battery Storage and Hydrogen Storage to Increase Photovoltaic Self-sufficiency in a Residential Building of Sweden. Energy Procedia 2016;103:268-273.

[57] Medium-Term Renewable Energy Market Report, OECD/IEA. International Energy Agency; 2013. URL http://www.iea. org/textbase/npsum/mtrenew2013sum.pdf

[58] Committee, F.C.S., et al. Information Report on the Development of a Hydrogen Quality Guideline for Fuel Cell Vehicles, SAE, J2719. International Organization for Standardization 2008;2:14687-2.

[59] Heinzel, A., Vogel, B., Hübner, P.. Reforming of natural gashydrogen generation for small scale stationary fuel cell systems. Journal of Power Sources 2002;105(2):202-207.

[60] Atsonios, K., Panopoulos, K., Doukelis, A., Koumanakos, A., Kakaras, E., Peters, T., et al. Introduction to palladium membrane technology. In: Palladium Membrane Technology for Hydrogen Production, Carbon Capture and Other Applications: Principles, Energy Production and Other Applications. Elsevier; 2014, p. 1-21.

[61] Aspen Plus user guide. Aspen Technology, Inc. Aspen Technology Limited, Cambridge, Massachusetts, United States; 2003.

[62] Campanari, S., Valenti, G., Macchi, E., Lozza, G., Ravidà, N.. Development of a micro-cogeneration laboratory and testing of a natural gas CHP unit based on PEM fuel cells. Applied Thermal Engineering 2014;71(2):714-720.

[63] Cozzolino, R., Cicconardi, S., Galloni, E., Minutillo, M., Perna, A.. Theoretical and experimental investigations on thermal management of a PEMFC stack. International Journal of Hydrogen Energy 2011;36(13):8030-8037.

[64] ASHRAE handbook fundamentals. Atlanta: American Society of Heating, Refrigerating and Air-Conditioning Engineers, Inc. ASHRAE; 1989.

[65] Sieverts, A.. Absorption of gases by metals. Zeitschrift für Metallkunde 1929;21:37-46.

[66] Hatlevik, Ø., Gade, S.K., Keeling, M.K., Thoen, P.M., Davidson, A., Way, J.D.. Palladium and palladium alloy membranes for hydrogen separation and production: history, fabrication strategies, and current performance. Separation and $\mathrm{Pu}-$ rification Technology 2010;73(1):59-64.

[67] DOE Hydrogen and Fuel Cell Program. Last Accessed 2018. URL https : //www.hydrogen . energy.gov/

[68] Piga, A., Verykios, X.E.. An advanced reactor configuration for the partial oxidation of methane to synthesis gas. Catalysis today 2000;60(1-2):63-71.

[69] European Patent 94600005.6/13.07.94. U.S.A. Patent No. 6, 605 376. Aug. 12.2003.

[70] Fogler, H.S.. Elements of Chemical Reaction Engineering (Prentice Hall International Series in the Physical and Chemical Engineering Sciences)(Hardcover). 2005.

[71] Kreith, F., Manglik, R.M., Bohn, M.S.. Principles of heat transfer. Cengage Learning; 2012.

[72] Dybkjaer, I.. Tubular reforming and autothermal reforming of natural gas an overview of available processes. Fuel Processing Technology 1995;42(2):85 - 107. Trends in Natural Gas Utilisation; URL http://www.sciencedirect.com/science/ article/pii/037838209400099F 